\title{
Catarina Juliana e suA SOCIEDAde DE CULTO: RITUAIS E PRÁTICAS RELIGIOSAS NA ANGolA SETECENTISTA
}

\author{
Daniel Precioso \\ (iD) \\ Universidade Estadual de Goiás
}

m 14 de novembro de 1750, a preta forra Catarina Juliana foi
presa em Angola e enviada para os cárceres secretos da inquisição
portuguesa, em Lisboa. Ela contava, então, quarenta anos de idade e residia em Ambaca, onde vivia amancebada com o capitão-mor do presídio. Ao ser presa, Catarina Juliana era senhora de quatro escravas e trazia no corpo vários enfeites de ouro e prata (cordões, verônica, brincos e fivelas) - bens adquiridos pelo seu sacerdócio, ou seja, pelos pagamentos recebidos por suas consultas de cura e adivinhação.

Catarina Juliana era uma figura atlântica. Nascida e batizada em Luanda, esteve na Bahia e em Lisboa. Sua saga terminou no Presídio de Ambaca, quando foi presa e enviada para Lisboa sob a acusação de realizar "feitiços”, “cultos diabólicos” e "adoração de ídolos”. O objetivo deste artigo é descrever e interpretar, a partir de uma etnomorfologia histórica comparada, as práticas religiosas ${ }^{1}$ realizadas por Catarina Juliana e sua sociedade de culto em uma região interiorana do Reino de Angola.

1 Procurar-se-á enfatizar, como os antropólogos, “a maneira como os indivíduos humanos concebem e usam seus recursos religiosos - crenças, objetos, textos, rituais e especialistas - em contextos sociais específicos por razões sociais e pessoas específicas. Ou seja, estamos menos interessados na doutrina de uma religião e mais na prática vivenciada da religião”. Jack David Eller, Introdução à antropologia da religião, Petrópolis: Vozes, 2018, p. 17. 
Cada ritual citado pelas testemunhas será interpretado mediante uma análise hermenêutica. ${ }^{2}$

A análise seguinte ampara-se no códice "Correspondência de Catarina Juliana”, localizado em meio aos "registros avulsos" do Tribunal do Santo Ofício da Inquisição de Lisboa, no Arquivo Nacional da Torre do Tombo. ${ }^{3}$ Trata-se de um processo inquisitorial com acentuado valor etnográfico, haja vista as descrições feitas pelas testemunhas de nomes de rituais e entidades em língua quimbundo. Os que acusaram Catarina Juliana, diferente dos denunciantes dos calundus coloniais, eram profundos conhecedores das práticas religiosas angolanas - o que permitiu a identificação de diversos rituais que, embora compartilhassem o transe, as danças, os batuques e os ritos de cura e adivinhação, não foram indistintamente rotulados de "calundus”. Uma descrição com menor interferência do etnocentrismo cristão também se faz presente nos testemunhos do processo de Catarina Juliana, o que se explicita na já referida nomeação de entidades, rituais e tipos de sacerdócio em quimbundo.

O processo de Catarina Juliana tem 353 páginas manuscritas, contendo o inventário dos seus bens, a sua genealogia, os autos de acusação, a sua confissão, os artigos de sua defesa e, o que é mais significativo, dois termos de assentada - um deles com a cópia dos quinze testemunhos que deram origem ao processo e outro com nove testemunhas adicionais -, além dos autos de reperguntas de treze testemunhas a partir das réplicas propostas pelo advogado de defesa da ré. Como Catarina Juliana faleceu nos cárceres da inquisição, nove testemunhas adicionais foram ouvidas para esclarecer as condições da sua morte.

2 Entende-se por ritual "o comportamento formal prescrito para ocasiões não devotadas à rotina tecnológica, tendo como referência a crença em seres ou poderes místicos”. Victor Turner, Floresta de símbolos: aspectos do ritual Ndembu, Niterói: EdUFF, 2005, p. 49.

3 Arquivo Nacional da Torre do Tombo (ANTT), Lisboa, Tribunal do Santo Ofício da Inquisição de Lisboa (TSOIL), Documentos Avulsos (DA), cx. 1580, cód. 13839, Correspondência de Catarina Juliana, 05/07/1756 a 05/10/1764. 
O processo de Catarina Juliana torna-se tanto mais relevante na medida em que permanece pouco conhecido e explorado pelos historiadores das religiões africanas - apenas dois historiadores se referiram ao caso. A historiadora portuguesa Maria Antonieta Garcia, no artigo “Doentes nos cárceres da Inquisição”, faz uma rápida citação de Catarina Juliana para arrolar a causa de sua morte, por “estupor e apoplexia”, no interior do cárcere inquisitorial. ${ }^{4} \mathrm{O}$ único estudo inteiramente dedicado ao caso de Catarina Juliana é o artigo de Kalle Kananoja, publicado em 2010 no International Journal of African Historical Studies. ${ }^{5}$ Este estudo é da maior importância para este artigo, mas nossa interpretação - como ficará claro - se distancia substancialmente da do africanista finlandês, que opera o conceito de crioulização. Entre os africanistas brasileiros, não identificamos sequer uma citação ao processo de Catarina Juliana, talvez porque as pesquisas destes se pautaram, sobretudo, em processos abertos a partir de denúncias contidas nos “Cadernos do Promotor” - como, aliás, é o caso do conhecido processo da calunduzeira Luzia Pinta. ${ }^{6}$ Assim, o presente artigo traz a lume, pioneiramente, uma análise aprofundada das descrições etnográficas das práticas religiosas africanas realizadas pela sociedade de culto de Catarina Juliana na Angola do século XVIII.

Os rituais religiosos estudados neste artigo são compreendidos a partir do aparato conceitual da antropologia simbólica. A iniciação de Catarina Juliana e a reedição de rituais funerários, celebrados pela sua

4 Maria Antonieta Garcia, “Doentes nos cárceres da inquisição”, Cadernos de Cultura, n. 12 (1998), p. 42.

5 Kalle Kananoja, "Healers, Idolaters, and Good Christians: A Case Study of Creolization and Popular Religion in Mid-Eighteenth Century Angola”, International Journal of African Historical Studies, v. 43, n. 3 (2010), pp. 443-465.

6 A pesquisadora Flávia Gomes Chagas está desenvolvendo uma dissertação de mestrado sobre Catarina Juliana pelo Programa de Pós-Graduação em História da Universidade Federal de Minas Gerais (NE: a dissertação foi defendida em fevereiro de 2021, após a aprovação deste artigo). Sobre a calunduzeira Luzia Pinta, cf. Alexandre A. Marcussi, "Cativeiro e cura: experiências religiosas da escravidão atlântica nos calundus de Luzia Pinta, séculos XVII-XVIII”, Tese (Doutorado em História), Universidade de São Paulo, São Paulo, 2015; Luiz Mott, “O calundu angola de Luzia Pinta: Sabará, 1739”, Revista IAC, v. 2, n. 11 (1994), pp. 73-82. 
comunidade religiosa em meio a baobás, são entendidas a partir da ideia de liminaridade, que, como definiu Arnold Van Gennep, é uma fase específica na sequência-padrão dos rituais de passagem. De acordo com o modelo de Van Gennep, os ritos de passagem compreendem três diferentes momentos (ou sub-ritos): a separação, a transição (aspecto propriamente liminar) e a reagregação. ${ }^{7}$ Como os rituais realizados pela sociedade religiosa de Catarina Juliana destinavam-se ao apaziguamento de espíritos ou à descoberta de feiticeiros e criminosos, recorremos ao conceito de drama social, que, segundo Victor Turner, abarca quatro etapas: a ruptura social (crise), a intensificação da crise, a ação reparadora e o desfecho (que pode levar à harmonia ou à cisão social). ${ }^{8}$

$\mathrm{Na}$ antropologia simbólica turneriana, como no presente artigo, os rituais envolvem uma transição, tanto no sentido da passagem de uma condição à outra quanto no da resolução de conflitos sociais - como, por exemplo, se deu, como se verá, nos juramentos de bulungo realizados pela sociedade religiosa de Catarina Juliana. Durante o ritual, a sociedade religiosa promotora transformava-se no que Turner chamou de communitas, já que retornava a uma forma de relação primordial, diferente daquela bem estruturada e hierarquizada que vigorava no cotidiano. ${ }^{9}$ A resolução dos conflitos se dava pela suspensão temporária do tempo humano (gerada pelo transe do sacerdote oficiante) e pela conexão entre os planos visível e invisível. Ao fim da liminaridade, as pessoas que passavam pelo ritual eram reintegradas na sociedade de uma maneira diferente, isto é, com status diversos - seja porque se iniciaram na seita, seja porque se curaram ou porque foram absolvidas ou condenadas por algum desvio moral.

O procedimento analítico aqui utilizado para o trato do processo inquisitorial de Catarina Juliana foi tomado de empréstimo do historiador italiano Carlo Ginzburg. Como Ginzburg, procura-se “olhar por cima

7 Arnold Van Gennep, The Rites of Passage, Chicago: The University of Chicago Press, 1960.

8 Victor Turner, Schism and Continuity in an African Society, Manchester: Manchester University Press, 1996.

9 Victor Turner, O processo ritual: estrutura e anti-estrutura, Petrópolis: Vozes, 1974. 
dos ombros" dos inquisidores, buscando as vozes perdidas dos homens e mulheres presos nos cárceres do Santo Ofício. ${ }^{10} \mathrm{~A}$ análise a seguir inspira-se, ainda, em uma etnologia histórica comparada, ou seja: em interpretações e reconstruções dos rituais citados a partir da literatura especializada, sobretudo, de processos inquisitoriais de outros "feiticeiros” africanos e de relatos de práticas religiosas angolanas deixados por governadores, missionários e viajantes que estiveram na região entre os séculos XVII e XVIII.

\section{Catarina Juliana: uma biografia}

Catarina Juliana nasceu escrava na freguesia da Sé da Cidade de São Paulo de Luanda, Reino de Angola, na década de 1710. Seus pais - já falecidos quando da sua prisão, em 1750 - eram Paulo Eugênio (alfaiate, escravo do padre João Clamor) e Juliana Salvador (escrava de Josefa Florim Correia e do sargento-mor Cipriano da Silva), ambos naturais e moradores, por toda a vida, da mesma Cidade de Luanda. Seus avós maternos, também já defuntos em 1750, eram João Esperança e Domingas Antônio, escravos da mesma senhora de Juliana Salvador, mãe de Catarina Juliana. Catarina teve duas irmãs, Cecília e Constança, falecidas precocemente. ${ }^{11}$

Apesar de ser natural da África, Catarina Juliana era uma escrava crioula, uma vez que nasceu na casa do seu senhor e seus pais eram católicos. À época de sua prisão, sua aparência física era a de uma "preta clara, que na terra se chama fulada, de estatura média e cheia de corpo", "já com alguns cabelos brancos" por ser de "meia idade". ${ }^{12}$ "Nas fontes e

10 Carlo Ginzburg, O fio e os rastros: verdadeiro, falso, fictício, São Paulo: Companhia das Letras, 2007, p. 292.

11 ANTT, TSOIL, DA, cx. 1580, cód. 13839, Correspondência de Catarina Juliana, fl. $5 \mathrm{v}$.

12 ANTT, TSOIL, DA, cx. 1580, cód. 13839, Correspondência de Catarina Juliana, fl. 99v, 103, 108, 111, 118v, 109, 96v, 101. 
na testa”, Catarina Juliana tinha "umas sarjas”, ${ }^{13}$ isto é, pequenos cortes superficiais na pele que produziam cicatrizes mais ou menos pronunciadas e que serviam como marca étnica ou emblema de identidade de seu grupo. Essas escarificações revelam que Catarina Juliana e seus pais, embora se declarassem católicos e batizados, mantiveram as suas tradições culturais, trazendo na face as marcas das suas origens étnicas.

Quando solteira, Catarina teve uma filha natural do capitão-mor do Presídio de Ambaca, o português João Pereira da Cunha, que faleceu com apenas oito meses de vida. Catarina Juliana já andava amancebada com João Pereira da Cunha em Luanda, quando ainda pertencia ao seu primeiro senhor, o sargento-mor Cipriano da Silva. ${ }^{14} \mathrm{O}$ futuro capitão-mor de Ambaca a comprou "por ter com ela [...] trato e amizade ilícita” ${ }^{15}$ e, assim que a adquiriu, concedeu-lhe a carta de alforria. Na escravidão africana, como observou Paul Lovejoy, era costume integrar cativas às parentelas, tomando-as por esposas: “as mulheres escravas tornavam-se dependentes livres, principalmente depois de terem filhos de um homem livre". ${ }^{16}$ Uma vez liberta, atuando como xinguila - sacerdotisa que incorporava espíritos para realizar curas e adivinhações -, Catarina pôde acumular bens devido à "celebridade [que gozava por] todas as mágicas de que usava”. ${ }^{17}$

13 ANTT, TSOIL, DA, cx. 1580, cód. 13839, Correspondência de Catarina Juliana, fl. 107-109. Bluteau define "sarja" como uma "abertura com lanceta na carne para tirar sangue.”, cf. Raphael Bluteau, Vocabulario portuguez \& latino: áulico, anatômico, architectonico..., Coimbra: Collegio das Artes da Companhia de Jesus, 1712-1728, t. 7, p. 502. Nas sociedades africanas, esta incisão superficial na pele, feita com bisturi, não tinha função medicinal, como definiu Bluteau, mas simbólica, servindo como marcador da identidade étnica.

14 ANTT, TSOIL, DA, cx. 1580, cód. 13839, Correspondência de Catarina Juliana, fl. 60 .

15 ANTT, TSOIL, DA, cx. 1580, cód. 13839, Correspondência de Catarina Juliana, fl. $4 \mathrm{v}$.

16 Paul Lovejoy, A escravidão na África: uma história de suas transformações, Rio de Janeiro: Civilização Brasileira, 2002, p. 46.

17 ANTT, TSOIL, DA, cx. 1580, cód. 13839, Correspondência de Catarina Juliana, fl. 101. 
Para tanto, ela possuía a licença do capitão-mor, seu amásio, para “possuir e usar o que lucrava [...] em seus próprios contratos”. ${ }^{18}$

Catarina Juliana não sabia ler nem escrever, mas detinha um prestigiado savoir faire religioso, oriundo da tradição oral angolana, que adquiriu durante as práticas iniciáticas as quais foi submetida. Quando começou o seu suplício, no dia 14 de novembro de 1750, ao chegar de Angola presa com o capitão-mor ${ }^{19}$ em Lisboa, Catarina possuía três escravas (de nação rebolo, anginga e zua) e muitas joias de ouro, bens que juntou pela sua atuação como xinguila (médium de espíritos). Os objetos de ouro, muitos deles permeados de simbolismo religioso, eram compostos por cordões, verônicas, pares de brincos, fivelas e uma pombinha (Espírito Santo). Ela possuía, ainda, cordões de prata, "três colares de coral vermelho, que lhe serviam no braço", ${ }^{20}$ além de "50 ou 60 moedas de dois mil e 800 réis cada uma, tudo em ouro”. A soma dos seus bens totalizava a relevante quantia de 548 mil e 600 réis. $^{21}$

18 ANTT, TSOIL, DA, cx. 1580, cód. 13839, Correspondência de Catarina Juliana, fl. 2. O próprio capitão-mor é apontado como mágico "público e notório" durante o processo de Catarina, mas não sabemos se ele era sacerdote (nganga) ou médium (xinguila).

19 De acordo com a testemunha João Soares Pereira, soldado do Presídio de Ambaca, com eles foram presos outros quatro "pretos livres", um deles chamado João Pedro e os outros apelidados de Mucuri, Quipaquina e Dalla Tango. ANTT, TSOIL, DA, cx. 1580, cód. 13839, Correspondência de Catarina Juliana, fl. 66v.

20 Em diversas culturas africanas, o coral - oriundo do mar - era considerado um material nobre e valioso por estabelecer relações simbólicas com forças da natureza que habitavam as águas. Cf. Aurea Conceição Pereira Tavares, "Vestígios materiais nos enterramentos na antiga Sé de Salvador: postura das instituições religiosas africanas frente à igreja católica em Salvador no período escravista”, Dissertação (Mestrado em Arqueologia), Universidade Federal de Pernambuco, Recife, 2006, p. 55. Como Catarina Juliana incorporava - como veremos - Gangazumba, entidade que habita pântanos e manguezais, pode ser que os colares de coral vermelho que ela trazia presos ao braço fossem uma representação simbólica deste nkisi. No Golfo do Benin e na África Central (Reino de Mutapa), a nobreza do coral também se devia ao fato dele ser um símbolo da realeza. Cf. Claire C. Davison e Robert D. Clark, "Two Chemical Groups of Dichroic Glass Beads from West Africa”, Man, v. 6, n. 4 (1971), pp. 645-659; H. H. K. Bhila, “A região ao sul do Zambeze” in Bethwell Allan Ogot (ed.), História geral da África, V: África do século XVI ao XVIII (Brasília: UNESCO, 2010), p. 804.

21 ANTT, TSOIL, DA, cx. 1580, cód. 13839, Correspondência de Catarina Juliana, fl. $1 \mathrm{v}-2 \mathrm{v}$. 
Por ter nascido escrava na Cidade de São Paulo de Luanda, sede política do reino de Angola (colônia portuguesa), Catarina foi introduzida no catolicismo desde o seu nascimento, mas herdou, também, as práticas religiosas tradicionais africanas. Ela teria levado uma vida dupla em termos religiosos: se não se relacionava com a religião local desde tenra idade, ao menos depois de ser acometida por uma enfermidade foi iniciada como médium (xinguila) e sacerdotisa (nganga-nkisi). Catarina foi batizada na Igreja da Conceição da Sé de Angola por um padre chamado André, então cura da mesma freguesia. Seus padrinhos foram um tal José, preto livre, e Bárbara Rodrigues, preta forra. Catarina foi crismada pelo bispo de Luanda na Igreja de Nossa Senhora do Rosário da freguesia da Sé. Perante os inquisidores, ao informar a sua genealogia, Catarina se declarou "verdadeira católica" - pois ouvia missa e pregação, confessava, comungava e fazia as demais obras - e, para provar o que disse, pôs-se de joelhos, persignou-se e benzeu-se, recitando o Padre Nosso, a Ave Maria, o Credo e os Mandamentos da Lei de Deus, comprovando, assim, o conhecimento dos preceitos fundamentais da fé dos colonizadores.

Catarina Juliana jamais saiu dos domínios de Portugal, mas, além de ter residido em Angola (na Cidade de São Paulo de Luanda e no Presídio de Ambaca), passou pela Cidade da Bahia e por Lisboa. Era, portanto, uma personagem atlântica, dado que havia circulado pelas diferentes margens do Atlântico Sul português. Embora tenha justificado suas viagens em razão de transações comerciais e políticas de seu ex-senhor e amásio, o capitão-mor do Presídio de Ambaca, ao circular pelo espaço atlântico português, Catarina Juliana também propagou as suas práticas religiosas, sendo mais uma das sacerdotisas africanas a disseminar os seus conhecimentos pelas regiões que percorreu, ajudando, assim, a moldar os calundus coloniais que se difundiram por toda a América portuguesa e até mesmo no Reino de Portugal. ${ }^{22}$

22 Sobre as práticas religiosas africanas em Portugal, ver: Daniela Buono Calainho, Metrópole das mandingas: religiosidade negra e inquisição portuguesa no Antigo Regime, Rio de Janeiro: Garamond, 2008. 
Na Corte portuguesa, enquanto estava presa, Catarina vivenciou os efeitos do terremoto de $1^{\circ}$ de novembro de 1755 .

Catarina Juliana era ré primária no Santo Ofício quando caiu, em 1750, nas malhas da inquisição portuguesa (juntamente com o seu ex-senhor e amante, o capitão-mor João Pereira da Cunha), ambos acusados de “idolatrias” e “adorações demoníacas”. Durante os treze anos em que esteve presa nas sombrias dependências da casa dos Estaus, onde ficavam os cárceres secretos da Inquisição de Lisboa, Catarina mudou a sua estratégia de defesa. Durante os primeiros interrogatórios de que temos conhecimento, realizados em 1756, rechaçou veementemente todas as acusações contra si, mas, após quase oito anos de cárcere, confessou que procurou uma nganga no Sertão de Angola para se curar de uma enfermidade. Sua confissão manteve um grau de passividade na condução das práticas religiosas em que se encontrava enredada que não condiz com a realidade. Os inquisidores não se deram por satisfeitos e, no decorrer do processo, fizeram ouvir novamente as testemunhas em Angola, incluindo ainda outros depoimentos no processo.

Durante toda a lenta coleta de provas, Catarina amargou as péssimas condições dos cárceres inquisitoriais. Contando mais de 45 anos de idade, sucumbiu, encarcerada, na noite do dia 8 de outubro de 1763. Apesar do auto de falecimento documentar a sua morte como "natural", causada por uma "espécie de estupor” ou "apoplexia” que a deixou “entrevada na cama por mais de três meses”, o longo período de reclusão, a alimentação ruim e a insalubridade do local é que ceifaram a sua vida. Como observou Daniela Buono Calainho, embora apenas uma minoria de negros e mulatos feiticeiros $(4,6 \%)$ tenha subido os cadafalsos portugueses dos tribunais de Lisboa entre os séculos XVI e XVIII, muitos tiveram as suas vidas destruídas, física e emocionalmente, pelos longos anos de prisões. $^{23}$

23 Calainho, Metrópole das mandingas, pp. 252, 254. 
Catarina Juliana faleceu encarcerada nas casas dos Estaus do Santo Ofício de Lisboa em companhia das suas parceiras de cela, a madre Mariana Inácia de São José, Inácia Maria, Gracia Maria e a preta Rosa Maria. A perda de consciência e mobilidade (estupor) foi causada por um acidente vascular, isto é, pelo derramamento de sangue no interior de um órgão (apoplexia). No longo tempo em que ficou "entrevada” na cama, e a título de "piedade” dos seus algozes, Catarina Juliana foi medicada sem êxito. Antes de falecer, recebeu diversas vezes os sacramentos da Comunhão (sagrado viático) e o da Extrema Unção, sendo antes confessada por um padre capelão. ${ }^{24}$

\section{Xinguila e nganga-nkisi: a iniciação de Catarina Juliana}

Por diversas vezes, frente a frente com os inquisidores, Catarina Juliana refutou as acusações de idolatria e gentilismo, afirmando-se fiel à "infalível verdade da religião católica”. ${ }^{25}$ Manteve essa estratégia de defesa por oito anos, mas, no interrogatório de 24 de julho de 1758, provavelmente em razão da pressão psicológica e das péssimas condições de seu já prolongado encarceramento, confessou que recorreu a um "mágico do sertão” (nganga) para se curar de uma moléstia.

Segundo a ré, treze ou quatorze anos antes, no presídio de Ambaca, achando-se doente, com o corpo todo inchado, procurou um preto forro chamado Mateus Capichi, "gentio, mas já batizado e morador junto ao dito presídio, no Sítio chamado o Gristago". ${ }^{26}$ Foi esse preto forro que lhe indicou uma curandeira. Catarina Juliana disse aos inquisidores que,

24 ANTT, TSOIL, DA, cx. 1580, cód. 13839, Correspondência de Catarina Juliana, fl. 167.

25 ANTT, TSOIL, DA, cx. 1580, cód. 13839, Correspondência de Catarina Juliana, fl. 11, passim.

26 ANTT, TSOIL, DA, cx. 1580, cód. 13839, Correspondência de Catarina Juliana, fl. $43 \mathrm{v}$ 
como não pretendia que o seu ex-senhor e amásio soubesse que procurava a cura por meios “gentílicos” - o que era mentira, pois ele próprio também o fez,$-{ }^{27}$ saiu às escondidas, em uma noite, para a casa de uma preta livre chamada Esperança Cazolla, "gentia não batizada, solteira [...] e natural do sertão, moradora no sítio de Anatunga, a légua e meia distante do dito presídio [de Ambaca]”. ${ }^{28}$ Acompanhou-a até a casa da curandeira sua escrava Antônia. Catarina Juliana confessou que foi

levada em uma rede por dois escravos da casa, chamados Mateus e João, os quais vendeu o mesmo capitão na Cidade da Bahia, e chegando à dita casa, ainda de noite se recolheu em particular com a dita Esperança e, comunicando-lhe as suas queixas, lhe disse a mesma que ela confitente tinha no corpo Quibuco e Mottâ [na verdade, como veremos, Gangazumba ${ }^{29}$ ], que são os nomes de dois ídolos da gentilidade, segurando-lhe que havia de curar e, para isso, entrou a tocar atabales e a bailar com outros pretos e pretas, que logo se ajuntaram, batendo todos as palmas das mãos, como também ela confitente, que estava sentada no chão, chamando todos pelos sobreditos ídolos e fazendo a dança chamada de calundus, na qual gastaram perto de uma hora e, depois de acabada, matou a dita Esperança um galo, que na dita dança tinha trazido na mão e, tomando-lhe o sangue em uma tigela, o misturou com uns pós de ervas, cujos nomes ignora, e com ele untou o corpo dela confitente, que logo se recolheu para casa sem experimentar melhoras. ${ }^{30}$

27 Concordamos, neste ponto, com Kananoja, “Healers, Idolaters, and Good Christians”, p. 464.

28 ANTT, TSOIL, DA, cx. 1580, cód. 13839, Correspondência de Catarina Juliana, fl. 43v.

29 A maioria das testemunhas ouvidas no processo apontaram Gangazumba como entidade possuída por Catarina Juliana. Pode ser, então, que, na sua confissão, a ré citou dois diferentes minkisi para despistar os inquisidores.

30 ANTT, TSOIL, DA, cx. 1580, cód. 13839, Correspondência de Catarina Juliana, fl. 44 . 
Catarina Juliana e Esperança Cazolla ajustaram que a cura deveria ser acabada na casa do capitão-mor João Pereira da Cunha. A curandeira recebeu de pagamento "seis varas de pano de linho"31 e, então, Esperança Cazolla visitou Catarina Juliana por quatro vezes,

aonde lhe trazia os pós das ditas ervas, que misturava com azeite de carrapato, e com ele lhe repetia as ditas venturas com as quais foi melhorando pouco a pouco; depois do que, encontrando-se ela confitente com a dita Esperança por algumas vezes, a mesma lhe pedia que lhe mandasse alguma coisa para os seus ídolos, o que, com efeito, fez, mandando-lhe em diversas ocasiões frascos de água ardente e pedaços de carne de porco, sabendo ela confitente que tudo era para oferecer no modo gentílico aos ditos ídolos, aos quais é certo que ajudou a idolatrar, batendo as palmas como acima tem declarado e se adoravam na cabeça da dita Esperança, aonde os gentios creem que eles entram. ${ }^{32}$

Para justificar o que acabara de confessar e se eximir da culpa, Catarina Juliana afirmou - faltando com a verdade - que nunca acreditou naqueles "ídolos” e que "só lhes deu a dita exterior adoração, que os mais pretos e pretas lhe davam na dita dança, para o fim de conseguir a saúde que desejava”. ${ }^{33}$ Mesmo mentindo não crer nos “ídolos”, ela acabou confessando que acreditava na eficácia dos rituais ambundus para a cura de doenças. Finalmente, disse - mais uma vez, faltando com a verdade - que não voltou a se encontrar com Esperança Cazolla e com os demais pretos e pretas do ritual que participou. ${ }^{34}$ Embora Catarina Juliana tenha tentado, em sua confissão, retratar a cerimônia descrita acima como uma mera

31 ANTT, TSOIL, DA, cx. 1580, cód. 13839, Correspondência de Catarina Juliana, fl. 44.

32 ANTT, TSOIL, DA, cx. 1580, cód. 13839, Correspondência de Catarina Juliana, fl. 44.

33 ANTT, TSOIL, DA, cx. 1580, cód. 13839, Correspondência de Catarina Juliana, fl. $44 \mathrm{v}$.

34 ANTT, TSOIL, DA, cx. 1580, cód. 13839, Correspondência de Catarina Juliana, fl. $44 \mathrm{v}$. 
consulta a uma curandeira, na realidade, a cerimônia não foi realizada apenas para a sua cura, mas também para a sua iniciação na sociedade religiosa de Esperança Cazolla, que se tornara a sua mentora religiosa.

A doença que acometeu Catarina Juliana era, na verdade, um chamamento dos deuses. Seu corpo havia sido apoderado por uma entidade ambunda: Gangazumba. Esperança Cazolla não pretendeu exorcizar a entidade, mas sim acomodá-la ao corpo da sua "paciente”. Como explicou Ioan Lewis, esse tratamento geralmente resulta de uma indução das pessoas afetadas pela doença a um grupo de culto que "promove experiências de possessão regulares entre seus membros. Dentro de um grupo de culto recluso, a possessão perde assim sua significação maligna”. ${ }^{35}$ A entidade ambunda que invadiu o corpo de Catarina Juliana e se manifestou por meio de uma enfermidade foi, portanto, domada e domesticada - e não expulsa. O galo sacrificado consistiu em uma oferenda (dádiva ou "taxa” paga) à entidade que possuiu o seu corpo. A aliança de Catarina Juliana com a entidade que requereu a sua iniciação se deu a partir do sangue do galo sacrificado. A unção do corpo de Catarina Juliana com o sangue aspergido do galo sacrificado serviu de preparação para a sua reconciliação com a divindade que se apossou do seu corpo, a partir da sua iniciação como sacerdotisa dessa mesma entidade. Desde então, Catarina Juliana incorporou os atributos da divindade, cujos poderes ela passou a mediar. ${ }^{36}$

O sacrifício realizado por Esperança Cazolla para a iniciação de Catarina Juliana na sua sociedade religiosa foi, ao mesmo tempo, de expiação e de comunhão, incluindo-se nos tipos de sacrifícios denominados curativos ou expiatórios. Catarina Juliana, enquanto sacrificante, foi ungida pela sacerdotisa oficiante com o sangue do galo sacrificado, ficando, assim, consagrada para a entrada no ritual de iniciação-comunhão com a entidade que havia possuído o seu corpo e se manifestado por meio

35 Ioan M. Lewis, Êxtase religioso: um estudo antropológico da possessão por espírito e do xamanismo, São Paulo: Editora Perspectiva, 1977, p. 31.

36 Sobre o significado do sangue do sacrifício e os atributos dos iniciados durante feitiços de cura (ou cultos de aflição) bantu, cf. Wyatt MacGaffey, "Fetishism Revisited: Kongo 'Nkisi' in Sociological Perspective”, Africa, v. 47, n. 2 (1977), pp. 176-177. 
de uma moléstia. Esperança Cazolla, sacerdotisa que realizou o sacrifício, encontrava-se, então, no limiar do mundo visível e do mundo invisível, simultaneamente representando-os e unindo-os. Sob o seu conjuro, a divindade não foi apenas "convidada a participar do sacrifício, mas a descer sobre a oferenda". ${ }^{37} \mathrm{O}$ animal sacrificado foi o intermediário pelo qual a corrente se estabeleceu; graças a ele, todos os seres que participaram do sacrifício se uniram e todas as forças que nele intervieram se confundiram.

Qual a razão, porém, do "chamamento" de Catarina Juliana? Provavelmente, a invasão do seu corpo foi uma represália de um antepassado ou de uma entidade da sua terra natal por ela "esquecida" ${ }^{38}$ No primeiro caso, Catarina Juliana pode ter sido negligente nas preces, oferendas e oblações devidas aos seus antepassados ou parentes mortos; no segundo caso, a sua mudança de Luanda para Ambaca pode ter gerado a ira de entidades africanas assentadas geograficamente em sua cidade natal, os quais eram seus ancestrais (antepassados mais distantes que fundaram a sua linhagem ou comunidade). ${ }^{39}$ Pode ser, ainda, que, tendo em vista o caráter oficial e dominante do catolicismo no reino de Angola, as entidades ambundas tenham se zangado com africanos que atuavam a favor dos portugueses, como era o caso de Catarina Juliana, amante do capitão-mor do Presídio de Ambaca. Como o culto público a essas

37 Marcel Mauss e Henri Hubert, Sobre o sacrifício, São Paulo: Ubu, 2017, pp. 37-38.

38 Como salientou Wyatt MacGaffey, "os objetos rituais centrais dos cultos dos ancestrais, dos espíritos locais e dos encantos (charms) não diferem nitidamente em forma, conteúdo ou função”. Cf. MacGaffey, “Fetishism Revisited”, p. 179. A única diferença entre a cura por nkisi e a cura por apaziguamento do antepassado, como observa o autor, é sociológica: a pessoa chamada a se iniciar no culto pela doença provocada pelo antepassado é um parente do espírito que se manifesta, enquanto aquela que não adoece por ação de um antepassado não tem relação com o nkisi "até que um ato divino decida que o encanto (charm) pode lidar com sua aflição. Muito frequentemente o encanto é representado como o iniciador da relação, como tendo imposto a aflição como um sinal que a pessoa em questão deve ser iniciada no culto deste encanto". Neste caso, "o iniciado incorpora os atributos do espírito cujos poderes ele media”. Cf. MacGaffey, "Fetishism Revisited”, p. 177.

39 Como observou Wyatt MacGaffey, os espíritos de ancestrais eram transformados, depois de muito tempo, em espíritos locais (bisimbi, basimbi, singular simbi). Cf. MacGaffey, "Fetishism Revisited”, p. 180. 
entidades ficou proibido dentro dos domínios portugueses de Angola, elas se manifestaram em africanos que habitavam esses mesmos domínios a fim de que eles mantivessem os seus cultos - ainda que de maneira periférica ou marginal. ${ }^{40}$

Embora a entidade ambunda tenha possuído o corpo de Catarina Juliana, a princípio ela não se manifestou pelo transe, ${ }^{41}$ mas por uma doença. Em um primeiro momento, houve uma possessão descontrolada, encarada como doença, e, em um segundo momento, um transe controlado, necessário para o exercício da sua mediunidade ou dom para intermediar as relações entre vivos e espíritos/entidades. O transe foi, assim, o recurso utilizado por Esperança Cazolla para domesticar o espírito invasor no corpo da sua "paciente”. Após revelar a sua vocação mediúnica, Catarina Juliana foi integrada como iniciada de um círculo de pessoas periodicamente possuídas, celebrando danças regulares e graduando-se ela própria à posição de sacerdotisa. Em sua gradual progressão na comunidade de culto de Esperança Cazolla, Catarina Juliana foi promovida de curandeira de infortúnios causados por espíritos (xinguila) - como é declaradamente classificada pelas testemunhas de seu processo - para sacerdotisa adoradora de entidades ambundas (nganga-nkisi) - o que não é textualmente apontado em seu processo, mas que podemos depreender. Pela liminaridade do ritual promovido por Esperança Cazolla, Catarina Juliana mudou de status, passando à condição de médium de espíritos (xinguila)

40 Embora reconheçamos a operacionalidade da distinção entre "cultos periféricos” e "cultos centrais", sinalizada por Ioan Lewis, não acreditamos que os rituais promovidos por Catarina Juliana sejam de "revolta" ou que ela tenha se iniciado por ser mulher ou socialmente oprimida. Cf. Lewis, Exxtase religioso. Apesar de alforriada (ou seja, ex-escrava), Catarina Juliana era amante da principal autoridade militar do Presídio de Ambaca. Seja como for, a sua mediunidade e condição de sacerdotisa, além de permitir a acumulação de bens, possibilitava-lhe angariar maior poder de barganha junto ao seu amásio e à sociedade local - já que ela poderia demandar coisas em nome da entidade que incorporava.

41 Entendemos por "transe" um "estado de dissociação, caracterizado pela falta de movimento voluntário e, frequentemente, por automatismo de ato e pensamento, representados pelos estados hipnótico e mediúnico”. Lewis, Êxtase religioso, p. 41. Essa dissociação mental pode ser completa ou parcial e, muitas vezes, é acompanhada de “visões excitantes e alucinações”, cujo conteúdo nem sempre é lembrado. 
e sacerdotisa de nkisi (nganga-nkisi); sua antiga personalidade morreu para uma nova nascer. Catarina Juliana também passou a integrar uma sociedade de culto circunscrita em meio à sociedade de Ambaca, incorporando-se pela experiência da communitas a outras pessoas, suas sócias. Não atuava, portanto, sozinha, mas em sociedade.

\section{A sociedade religiosa de Catarina Juliana}

As testemunhas do processo acusaram a ré Catarina Juliana de praticar “feitiçarias gentílicas”. Recaía sobre ela, mais precisamente, a denúncia de que, "em companhia de certas pessoas suas sócias, colocava em certa casa os ídolos de gentilidade [...] trazidos de casa de certos mágicos, donde estavam depositados”. ${ }^{42}$ Nestes rituais, a sociedade dava “culto e adoração [aos ídolos], tocando timbales e adufes e cantando, bailando e batendo as palmas ao modo gentílico, e pondo-se de joelhos e falando com eles com palavras submissas e reverentes". ${ }^{43}$ A sociedade religiosa pretendia com esses “festejos” consultar “os ditos ídolos, que invocavam recebendo resposta dos mesmos sobre o que [se] pretendia saber e alcançar, ainda a respeito dos futuros contingentes, conseguindo por este meio a saúde nas enfermidades e fortuna avantajada nos negócios”. ${ }^{44}$

Essas reuniões eram presididas por “certos mágicos” - na verdade, sacerdotes ambundus (banganga em quimbundo; no singular, nganga) ${ }^{45}$ -

42 ANTT, TSOIL, DA, cx. 1580, cód. 13839, Correspondência de Catarina Juliana, fls. 22-22v.

43 ANTT, TSOIL, DA, cx. 1580, cód. 13839, Correspondência de Catarina Juliana, fls. 22-22v.

44 ANTT, TSOIL, DA, cx. 1580, cód. 13839, Correspondência de Catarina Juliana, fls. 22-22v.

45 O que os inquisidores chamavam de “mágicos” eram, na verdade, sacerdotes experimentados nas religiões bantu, responsáveis pelo treinamento de pessoas que queriam - ou receberam chamados de deuses e espíritos para - se tornar especialistas em rituais (banganga). Como observou Wyatt MacGaffey, para que uma pessoa se tornasse um nganga, ela deveria receber a orientação de um perito (mestre em "magia”) com “talentos extraordinários”, imprescindíveis para desenvolver no aprendiz as 
que a sociedade buscava fora do presídio de Ambaca. De acordo com as testemunhas ouvidas no processo, o núcleo central da sociedade religiosa era formado pelo dono da casa onde o grupo se reunia, o capitão-mor do presídio de Ambaca João Pereira da Cunha, por sua concubina Catarina Juliana, pelos seus escravos Teodósio e Josefa Parda ${ }^{46}$ e por uma negra chamada Luzia. Juntavam-se a eles o ajudante Felipe Dias Chaves e seu ex-escravo, o preto forro Antônio Cambundo, que foi apontado como o nganga mais poderoso da sociedade. ${ }^{47} \mathrm{O}$ vigário de Ambaca, João Velho de Barros, afirmou que foi esse preto forro que levou o capitão-mor João Pereira da Cunha em uma serpentina para fora do presídio, em "um sítio ou lugar chamado Canasangi”, ${ }^{48}$ para invocar as entidades e tocar atabaques a fim de curá-lo de uma grave enfermidade.

Uma testemunha ouvida no processo, além de nomear os outros banganga que integravam a sociedade religiosa de Catarina Juliana, assinalou quais eram as suas procedências: Antônio Cambundo residia em Lucamba, pertencente à jurisdição de Ambaca; Catumba Ca Quitacu, Esperança Cazolla (que iniciou Catarina Juliana), o soba Mumsa a Luamba e Dom Salvador Mucuri moravam no Bembegi, localidade

habilidades ou poderes sobrenaturais (kindoki) para interagir com o mundo espiritual e preparar medicamentos especiais (bilongo) a fim de atrair um determinado nkisi para um objeto encantado. Cf. Wyatt MacGaffey, Religion and Society in Central Africa, Chicago: The University of Chicago Press, 1986. Esses "mágicos”, portanto, não devem ser confundidos com os "feiticeiros" ou "bruxos" que agiam sozinhos (ou a mando de pessoas movidas por desafetos), atuando socialmente de forma disruptiva. Diferentes deles, os ngangas (chamados de "mágicos” pelos inquisidores no processo de Catarina Juliana) atuavam coletivamente e de maneira a restaurar o equilíbrio social por meio de seus rituais religiosos, presidindo, assim, a communitas durante os ritos liminares. Cf. Fábio Leite, "Bruxos e magos”, África: Revista do Centro de Estudos Africanos da USP, São Paulo, n. 14-15 (1991-1992), pp. 69-80.

46 Josefa Parda também é apontada como concubina do capitão-mor, o que é compreensível dentro da tradição poligâmica centro-africana.

47 Testemunhas do processo o apontaram como sendo o “principal mágico” envolvido nas cerimônias delatadas. Cf. ANTT, TSOIL, DA, cx. 1580, cód. 13839, Correspondência de Catarina Juliana, fl. 97v.

48 ANTT, TSOIL, DA, cx. 1580, cód. 13839, Correspondência de Catarina Juliana, fls. 96-97. 
também pertencente à jurisdição de Ambaca, nas proximidades do mesmo presídio. ${ }^{49}$ A essa lista de sacerdotes ambundus, outra testemunha acrescentou um preto chamado Dalla a’ Quipaquina, morador “fora do dito presídio”. 50

Esses peritos em rituais ambundus eram trazidos dos sertões angolanos e forneciam os saberes e os objetos necessários para a criação da sociedade religiosa doméstica, integrada por Catarina Juliana. O caráter doméstico da sociedade religiosa aqui estudada se deve tanto ao fato dela estar sediada na casa do capitão-mor João Pereira da Cunha quanto ao caráter privado dos rituais nela praticados. As cerimônias contavam com danças de roda, cantos de solo e resposta coral, acompanhadas pelo som das batidas das palmas das mãos e dos tambores (ngoma). Apesar dos seus integrantes terem sido iniciados durante essas cerimônias, a casa do capitão-mor não assumiu um modelo organizacional de tipo conventual, como Luis Nicolau Parés observou entre os africanos ocidentais. ${ }^{51}$ A partir dos indícios coletados, parece mais factível que as iniciações se dessem em relações pontuais com vistas a curas.

Alexandre Marcussi observou que calundus de matriz bantu, como o de Luzia Pinta, se caracterizavam pela iniciação dos consulentes, desdobrando-se, inclusive, em instituições que reconstituíam ritualmente os laços de parentescos rompidos pela escravidão dentro do que o autor chamou - baseado em Claude Lévi-Strauss - de "inversão estrutural". ${ }^{52}$ Esse parece ser o caso da sociedade religiosa doméstica de Catarina Juliana: a iniciação não obedecia a um modelo conventual,

49 ANTT, TSOIL, DA, cx. 1580, cód. 13839, Correspondência de Catarina Juliana, fl. 98.

50 ANTT, TSOIL, DA, cx. 1580, cód. 13839, Correspondência de Catarina Juliana, fl. 103.

51 Luis Nicolau Parés, "Religiosidades” in Lilia Mortiz Schwarcz e Flávio dos Santos Gomes (orgs.), Dicionário da escravidão e liberdade: 50 textos críticos (São Paulo: Companhia das Letras, 2018), p. 380.

52 Cf. Alexandre A. Marcussi, "Utopias centro-africanas: ressignificações da ancestralidade nos calundus da América portuguesa nos séculos XVII e XVIII", Revista Brasileira de História, v. 39, n. 79 (2018), pp. 19-40. Marcussi notou que, em determinados calundus realizados por escravizados centro-africanos no Brasil colonial, os 
com período de noviciado e transmissão de conhecimentos nos moldes de um seminário, possuindo, ao invés disso, um caráter mais imediato. As iniciações ocorriam durante cerimônias de cura, de acordo com um modelo que podemos chamar, a partir dos apontamentos de Alexandre Marcussi, de modelo da cura-iniciação.

Apesar da ausência de uma estrutura de tipo conventual, a sociedade doméstica de culto integrada por Catarina Juliana revela a existência, na Angola setecentista, de associações de pessoas para cultuar minkisi e, por essa via, se distancia das definições dos calundus coloniais como cerimônias de cura-adivinhação realizadas por indivíduos isolados. Esse é um elemento a mais para refutar a tese - defendida por pioneiros dos estudos dos negros no Brasil, como Édison Carneiro e Roger Bastide - de que os angolas copiavam a estrutura organizacional dos terreiros nagôs. ${ }^{53}$ Parece correto afirmar, todavia, que, tanto entre os africanos ocidentais quanto entre os bantu, “a unidade doméstica estava na base do terreiro"; o apoio e a participação de pessoas influentes e de libertos mais prósperos - como era o caso de Catarina Juliana e do capitão-mor - eram fundamentais para a organização das comunidades e para arcar com os gastos das dispendiosas e intrincadas cerimônias. ${ }^{54}$

Como a iniciação de Catarina Juliana e, provavelmente, também a dos seus "sócios", ocorreu a partir de uma "aflição" - ou seja, de uma doença ocasionada por um espírito que possuiu o seu corpo -, a sua sociedade religiosa nasceu para aplacar crises coletivas. As causas das crises (doenças) podem envolver tanto feitiçarias feitas por desafetos locais do capitão-mor, amante de Catarina, quanto a ira de entidades

antepassados mortos eram chamados de "filhos", o que permitia a reconstituição de laços de parentesco por uma inversão estrutural.

53 Cf. Édison Carneiro, Negros bantos: notas de etnografia religiosa e de folclore, Rio de Janeiro: Civilização Brasileira, 1981, p. 30; Edison Carneiro, Candomblés da Bahia, Rio de Janeiro: Civilização Brasileira, 2002, p. 97. O sociólogo francês Roger Bastide, influenciado pelas considerações de Carneiro, também afirmou que as nações Congo e Angola copiaram as Nagô e Jeje, apenas trocando os nomes das divindades. Cf. Renato da Silveira, O candomblé da barroquinha: processo de constituição do primeiro terreiro baiano de keto, Salvador: Maiganga, 2006, p. 211.

54 Parés, “Religiosidades”, p. 380. 
territoriais e espíritos de antepassados negligenciados. É possível, ainda, que Catarina Juliana e seus “sócios” tenham desenvolvido rituais secretos parecidos com os kimpasi - cultos de aflição - para remediar tais crises coletivas ocasionadas por doenças que os acometeram.

Como definiu Robert Slenes, os kimpasi eram movimentos secretos comunitários com o objetivo de apaziguar os espíritos e solucionar crises coletivas. Esses rituais secretos envolviam a devoção de objetos sagrados, além do desenvolvimento de "língua secreta, reuniões nas clareiras das matas, iniciação através da morte ritual e do renascimento, o transe espiritual, isto é, a incorporação do espírito-guia, cujo nome e identidade carregava o [praticante] durante o resto da vida". ${ }^{55}$ Como veremos, os rituais feitos pela sociedade religiosa de Catarina Juliana no campo entre baobás sagrados e a nomeação de entidades bantu (minkisi) não conhecidas pelos inquisidores e habitantes locais ("Tulariam Bande", “Alutá” e os gêmeos "Pingi” e "Quitari Quiacuvimba”) parecem corroborar esta hipótese de que a sociedade de Catarina Juliana desenvolveu ritos secretos.

A organização de sociedades religiosas como a de Catarina Juliana não era homogênea na África Central. Como elucidou John K. Thornton, o sacerdócio na área bantu se dava por meio de um processo de "revelação contínua”, e a teologia dos povos da região era formada por uma "corrente constante de revelações não submetidas ao controle de um sacerdócio que impusesse uma ortodoxia. Em vez disso, ela era interpretada dentro de uma comunidade de fé”. ${ }^{56}$ Cada sociedade religiosa tinha, assim, uma forma específica de organização baseada nas contínuas revelações obtidas pelos seus sacerdotes supremos responsáveis pelas iniciações. Segundo

55 Robert Slenes, “A árvore de Nsanda transplantada: cultos kongo de aflição e identidade escrava no sudeste brasileiro (século XIX)” in Douglas Cole Libby e Júnia Ferreira Furtado (orgs.), Trabalho escravo, trabalho livre: Brasil e Europa, séculos XVIII e XIX (São Paulo: Annablume, 2006), pp. 288-289.

56 John K. Thornton, "Religião e vida cerimonial no Congo e áreas Umbundo, de 1500 a 1700” in Linda M. Heywood (org.), Diáspora negra no Brasil, 2ª ed. (São Paulo: Contexto, 2019), p. 84. 
Thornton, “os sacerdotes eram aqueles que demonstravam eficácia em contatar o outro mundo, uma habilidade que não era transferida por uma hierarquia ou seminário". ${ }^{57}$ Logo, cada casa de culto tinha a sua organização e transmitia os saberes através de iniciações que se davam dentro de uma estrutura pontual de tipo cura-iniciação, como a descrita por Marcussi, sendo os noviços iniciados de acordo com os saberes dos sacerdotes mais experientes, chamados no processo de “mágicos do sertão”.

\section{Os "mágicos do sertão"}

Como observou Selma Pantoja, "a região do interior, o chamado sertão angolano, era um mundo longe do controle dos europeus e, por isso mesmo, objeto de preocupação das autoridades portuguesas". ${ }^{58}$ Um édito do século XVIII determinava que os brancos que vagassem pelo interior de Angola e que "não estivessem sujeitos a viver unidos em sociedade, em religião, em justiça e em indústria” deveriam ser "presos e remetidos para, nesta capital [Luanda], servir como praça de soldado”. Para esse efeito, deveriam ser passadas “as ordens necessárias aos sobas e potentados e aos chefes ou juízes das outras povoações para que se procurem prender e entregar ao capitão-mor todo aquele que disperso vagar sem passaporte”. ${ }^{59}$

A tentativa de controle dos que circulavam pelos sertões angolanos foi, sem dúvida, muito precária, e muitos banganga de comprovada perícia (chamados de "mágicos do sertão" no processo) vagaram pelos entornos dos domínios portugueses na região sem passaporte, adentrando, inclusive, os presídios interioranos para realizarem suas práticas de cura e

57 Thornton, “Religião e vida cerimonial”, p. 84. Sobre essa teologia, ver: John K. Thornton, Africa and Africans in the Making of the Atlantic World, New York: Cambridge University Press, 1998, pp. 235-247.

58 Selma Pantoja, "Inquisição, degredo e mestiçagem em Angola no século XVIII", Revista Lusófona de Ciência das Religiões, v. 3, n. 5-6 (2004), p. 122.

59 Instituto Histórico e Geográfico Brasileiro (IHGB), Rio de Janeiro, Arquivos de Angola, 03/1936, v. 1, n. 6, doc. 5, p. 178, citado por Antonio Silva Rego, O ultramar português no século XVIII (1700-1833), Lisboa: Agência Ultramarina, 1967. 
adivinhação. A esses se associavam degredados, aventureiros e desertores, como revelou o governador de Angola Sousa Coutinho, que afirmou: "aqui não receberão os conquistados os costumes dos conquistadores, antes muito pelo contrário, estes se apropriarão [...] do gentilismo e da superstição”. ${ }^{60}$ Mesmo os angolanos batizados no catolicismo, nascidos e moradores nos três principais espaços urbanos portugueses de Angola Luanda, Benguela e Massangano - recorreram aos "cirurgiões mágicos" dos sertões para ter "bom sucesso em todos os negócios” e para se livrarem “de grandes doenças”, como demonstram as acusações contra a sociedade religiosa de Catarina Juliana. ${ }^{61}$

João Amado da Silva, capitão dos moradores do Presídio de Ambaca e almoxarife, em seu depoimento, afirmou que o capitão-mor João Pereira da Cunha,

achando-se em certa ocasião muito enfermo e muito perto da morte [mandou que fossem] chamados os seus referidos mágicos, para que soubessem de que enfermidade morria [...] e logo entraram os mágicos a fazer suas diabruras e o levaram assim moribundo o dito João Pereira da Cunha, rompendo os muros do quintal a um sítio chamado Canasangi perto do Presídio e aí fazendo-lhe suas mestrias diabólicas [... ${ }^{62}$

O “mágico” responsável por essa cerimônia foi o já citado Antônio Cambundo, o mais poderoso dos banganga da sociedade religiosa de Catarina Juliana. A eficácia da cura promovida por Antônio Cambundo foi relatada no mesmo testemunho: no dia seguinte à cerimônia, o capitão-mor pareceu "são e salvo, como se por ele não tivera passado coisa alguma”, ${ }^{63}$

60 Citado por Jofre Amaral Nogueira, Angola na época pombalina: o governo de Sousa Coutinho, Lisboa: [s. n.], 1960, p. 115.

61 ANTT, TSOIL, DA, cx. 1580, cód. 13839, Correspondência de Catarina Juliana, fls. 93-93v.

62 ANTT, TSOIL, DA, cx. 1580, cód. 13839, Correspondência de Catarina Juliana, fls. 99-99v.

63 ANTT, TSOIL, DA, cx. 1580, cód. 13839, Correspondência de Catarina Juliana, fls. 99-99v. 
Para extirpar de vez o mal, o capitão-mor deveria dar sequência aos rituais no interior de sua casa, onde se encontravam os minkisi das divindades cultuadas por Catarina Juliana e pelos demais membros da sua sociedade religiosa.

Em seu depoimento, João Teixeira, homem preto, oficial de alfaiate, natural do Presídio de Ambaca e assistente no Sítio de Calumba, afirmou que os “ídolos” adorados por Catarina e pelo capitão-mor João Pereira da Cunha foram fabricados por um nganga do sertão chamado Dalla a' Quipaquina, que os fez “de pau”. Ao que parece, Dalla a’ Quipaquina é, ao mesmo tempo, nome e tipo de sacerdócio. Literalmente, ndala a'kipa kina, em quimbundo, significa "sacrário de magia de sepultura”, sendo esse tanto o nome do mencionado fabricante dos "ídolos" quanto um modo de se referir ao nganga responsável por recolher, em uma caixinha (escatula), as relíquias dos antepassados de uma família. ${ }^{64}$ A mesma testemunha afirmou que, durante os rituais realizados fora do Presídio de Ambaca, entre as árvores chamadas imbondeiros, Catarina Juliana e seus sócios eram acompanhados pelo mesmo preto Dalla a’ Quipaquina e por Antônio Cambundo. Esse último, inclusive, teria fugido e se escondido após ter conhecimento da prisão do capitão-mor e de Catarina Juliana. ${ }^{65}$

Pistas para compreender o motivo da doença do capitão-mor João Pereira da Cunha e quais rituais foram realizados para a sua cura são encontradas em um processo analisado por Selma Pantoja. Em 1722, o capitão Antônio de Freitas, de Benguela, para curar-se de uma doença na perna - atribuída à alma de sua mulher morta - consultou um nganga que lhe recomendou a realização de um entambe, isto é, um ritual fúnebre para apaziguar a alma da falecida. Para tanto, realizou-se "uma festa de atabaques, em sua casa, pelas suas negras”. Para a realização da festa, o capitão mandou "matar dois bois e deu de comer e constou desse baile

64 A. de Assis Júnior, Dicionário kimbundu-português, linguístico, botânico, histórico e corográfico, seguido de um índice alfabético dos nomes próprios, Luanda: Argente, Santos \& Cia. Ltda., [19--], pp. 39-40, 131, 136.

65 ANTT, TSOIL, DA, cx. 1580, cód. 13839, Correspondência de Catarina Juliana, fls. 103-103v. 
suas negras e um homem ambundu”. ${ }^{66}$ Observamos aí, mais uma vez, a presença de um "mágico do sertão”, ou seja, de um especialista em rituais bantu. De acordo com Selma Pantoja: “As testemunhas disseram que o capitão Antônio de Freitas foi introduzido nas 'superstições’ por 'um feiticeiro ambundu'”. O feiticeiro era "figura chave da história”, mas, diferentemente do caso de Catarina Juliana, não foi citado nominalmente no processo do capitão Antônio de Freitas.

A função do nganga era exercer o ministério do culto, executando diferentes tipos de sacerdócios tanto em conjunto com outras pessoas quanto em particular. No último caso, prediziam o futuro e curavam doenças de clientes em troca de um pagamento. Como observou Selma Pantoja, o termo era "usado em áreas linguísticas muito amplas, e nem sempre o sentido é o mesmo" ${ }^{67} \mathrm{Na}$ região ambundu, o termo poderia abarcar o quimbanda (feiticeiro que causava malefícios à comunidade) e, em Benguela, era usado como sinônimo de sacerdote em geral, podendo também designar sabedoria. Já entre os europeus, os banganga costumavam ser vistos como agentes que usavam o "poder para fazer o mau, causar doenças e mortes”; embora, na maioria das vezes, como demonstra o processo de Catarina Juliana, ocorresse exatamente o contrário.

Existiam diversas modalidades de sacerdócio, "sendo uma delas a das doenças atribuídas aos castigos dos espíritos esquecidos”. 68 Os sacerdotes responsáveis por aplacá-los podiam ser chamados tanto de nganga-ia-zumbi quanto xinguila. Adotamos o último termo neste estudo por ser o utilizado no processo de Catarina Juliana, mas ambos os termos se referiam ao “sacerdote dos espíritos”. "Se alguém sonha com um dos seus mortos, ou se está com dúvida de não ter lembrado suficiente daquele espírito, recorre a um nganga-ia-zumbi [ou a um xinguila]”. ${ }^{69} \mathrm{Na}$ cosmo-

66 ANTT, TSOIL, Caderno do Promotor (CA), livro 285, fl. 235, Carta de denúncia contra o capitão Antônio de Freitas, 1722. Citado por: Pantoja, "Inquisição, degredo e mestiçagem”, p. 125.

67 Pantoja, “Inquisição, degredo e mestiçagem”, p. 127.

68 Pantoja, “Inquisição, degredo e mestiçagem”, p. 127.

69 Pantoja, “Inquisição, degredo e mestiçagem”, p. 127. 
logia bantu, o valor supremo da vida é a força vital. Para esses povos, o propósito da vida é obter essa energia, sendo todo infortúnio decorrente da perda dela. Para obter força vital, os bantu realizam sacrifícios e invocações às divindades e aos antepassados mortos, o que os europeus chamavam de "magia” ou "feitiçaria", mas que eram, aos olhos dos próprios bantu, maneiras de "ativar as forças naturais que o Ser Supremo pôs à disposição dos homens para aumentar sua energia vital”, ${ }^{70}$

A doença (perda de força vital) que acometeu o capitão-mor João Pereira da Cunha foi provocada por um antepassado morto. Para apaziguar esse antepassado, foi realizada uma espécie de reedição do ritual fúnebre chamado entambe, fora do presídio de Ambaca, na região onde se encontrava o seu túmulo. Posteriormente, rituais foram realizados na própria casa do capitão-mor por meio do culto às divindades personificadas nos minkisi e a um bode. Essas festividades contaram com batuques, adorações e sacrifícios de animais e foram realizadas, provavelmente, após o ritual no túmulo do antepassado morto, já fora do presídio. Esses rituais, que visavam aplacar a ira de um parente morto, integram o que Victor Turner chamou de rituais de aflição. De acordo com Turner, os ritos de aflição destinam-se à transformação de uma perturbação em poder curativo, já que “o adepto aplaca o espírito ofendido” em um processo que “traz o ancestral ofendido de volta à memória”. ${ }^{71}$

Os sertões angolanos eram locais em que predominavam a cultura, a religião e as línguas nativas. Até mesmo nos presídios do interior, o quimbundo e o quicongo continuaram a serem línguas francas. Os oficiais portugueses fizeram várias tentativas de banir essas línguas bantu dos ofícios religiosos nas regiões centrais de Angola; mesmo em Luanda, o quimbundo era comum, sendo inclusive usado por intérpretes na catequização da população local. Em 1760, quando oficiais da Coroa portuguesa tentaram banir sermões em quimbundo, substituindo-os pela

70 Placide Tempels, Bantu philosophy, Paris: Présence Africaine, 1969, p. 1.

71 Victor Turner, Schism and Continuity in an African Society, Manchester: Manchester University Press, 1996, p. 298. 
língua portuguesa, viram as suas tentativas frustradas, constatando que "nada pode ser feito sem o intermédio de um intérprete que é sempre um 'negro ladino", 72 ou seja, um crioulo africano. O governador Sousa Coutinho também viu malograr, em 1765, a sua tentativa de banir o quimbundo, “ordenando que as crianças não aprendessem essa língua e exigindo que fosse substituída no interior (sertões) pelo português", ${ }^{73}$ Em 1800, o governador de Benguela lamentou que os naturais da terra não aprendiam o português e, por isso, eram incapazes de ouvir missa em português e fazerem confissões. ${ }^{74}$

O uso franco das línguas bantu nos sertões angolanos torna-se evidente no processo de Catarina Juliana quando os banganga do sertão são nomeados em língua quimbundo. Isso demonstra que eles não eram batizados no catolicismo e viviam segundo as tradições culturais e religiosas angolanas. O historiador Silva Corrêa, que esteve no reino de Angola em fins do século XVIII, afirmou em sua História de Angola que a maioria dos habitantes dos reinos não católicos das regiões interioranas de Angola seguia as suas antigas crenças. Lamentava, ainda, que os portugueses estariam mais preocupados em coletar impostos nessas regiões do que em incutir o catolicismo. ${ }^{75}$

Para os especialistas em rituais bantu - chamados depreciativamente de "mágicos do sertão" no processo de Catarina Juliana - os "sertões” (termo português para designar terras que não estavam sob o domínio da Coroa) eram, na verdade, espaços sagrados. Como esclarece Bunseki Fu-Kiau, o mundo natural (florestas e campos abertos),

72 Citado por Carlos Couto, Os capitães-mores em Angola no século XVIII, Luanda: Instituto de Investigação Científica de Angola, 1972, p. 164.

73 Biblioteca Nacional de Lisboa (BNL), Fundo Geral (FG), cód. 8554, fls. 27-28, Carta de Sousa Coutinho, 1756. Citado por Linda M. Heywood, "De português a africano: a origem centro-africana das culturas atlânticas crioulas no século XVIII" in Linda M. Heywood (org.), Diáspora negra no Brasil (São Paulo: Contexto, 2019), p. 114.

74 Arquivo Histórico Ultramarino (AHU), Avulsos Angola, cx. 95, n. 18, Governador Vasconcelos ao ministro de Estado, 1800.

75 Elias Alexandre da Silva Corrêa, História de Angola, Lisboa: Clássicos da Expansão Portuguesa no Mundo, 1937, v. 2, pp. 194-195. 
na cosmologia bantu, é definido como um "rico laboratório da raça humana. É um laboratório sem paredes, que os bantu continuam a descobrir desde a sua mais tenra idade”. ${ }^{76}$ Os sertões angolanos, portanto, eram locais onde os banganga coletavam ervas, raízes, folhagens, cascas etc. para a preparação de remédios para as curas dos seus consulentes. $\mathrm{O}$ mundo natural era, ainda, o espaço para a iniciação de pessoas no sacerdócio da cura e adivinhação.

Como se viu, ao mesmo tempo em que se curavam no sertão, os doentes se iniciavam na sociedade religiosa. O modo de iniciação dos novos membros da sociedade religiosa de Catarina Juliana deve ter sido próximo ao descrito abaixo por Fu-Kiau:

O homem do remédio (nganga), curador da comunidade, gasta a maior parte do seu tempo dentro desses templos vivos, bibliotecas e laboratórios para "estudar” e coletar o remédio da comunidade. Para cada remédio ele canta uma cantiga com detalhes de como e quando o remédio é preparado e usado. Da mesma maneira, seus/suas seguidores (as) - bâna, literalmente “crianças”, aqueles a tornarem-se futuros banganga, repetirão - kumbu lula aquelas mesmas cantigas de remédio, bem como as suas próprias. Cantar os remédios corretamente e perfeitamente é um método popular para manter a receita do medicamento e é uma das mais importantes responsabilidades de um m'buki - curador entre os bantu. A arte de "cantar os remédios" é vista também como uma rotina diária espiritualmente sagrada do nganga. ${ }^{77}$

Ao retornar para a casa do capitão-mor, a sociedade religiosa de Catarina Juliana continuaria a recitar as orações, a preparar os remédios e a cultuar divindades personificadas em objetos rituais chamados minkisi.

76 Bunseki Fu-Kiau, “A visão Bântu Kôngo da sacralidade do mundo natural”, Associação Cultural de Preservação do Patrimônio Bantu - ACBANTU, n. 67, pp. 4-5.

77 Fu-Kiau, “A visão Bântu Kôngo”, pp. 4-5. 
Essas divindades foram chamadas de "filhos" da sociedade religiosa e serão analisadas a seguir. ${ }^{78}$

\section{Os minkisi: o continuum objeto-pessoa-divindade}

Catarina Juliana foi denunciada por adorar "ídolos da gentilidade”. Como católica batizada, era-lhe proibido retornar aos "cultos pagãos” da sua terra, pois, na ótica da inquisição, isso configurava um crime de idolatria e/ou adoração demoníaca. Na definição etnocêntrica dos portugueses, "ídolo" era uma "estátua de alguma falsa deidade"79 utilizada para fazer "feitiços demoníacos". Os "ídolos" referidos no processo de Catarina Juliana eram, na realidade, o que os bacongo e povos vizinhos chamavam de minkisi (no singular, nkisi): objetos rituais fabricados e que, quando invocados, produziam os efeitos desejados. ${ }^{80}$

Como observou Wyatt MacGaffey, a noção de "feitiço" (fetiche) - articulada à de "ídolo" (idolatria) - foi criada pelos portugueses que travaram contato com a África subsaariana a partir do século $X V^{81}$

78 ANTT, TSOIL, DA, cx. 1580, cód. 13839, Correspondência de Catarina Juliana, fl. 99-99v.

79 Bluteau, Vocabulario portuguez \& latino, t. 4, p. 34.

80 Esses objetos poderiam, no entanto, ter vontade própria e comandar o comportamento dos seres humanos. Wyatt MacGaffey, "The Personhood of Ritual Objects: Kongo Minkisi”, Etnofoor, n. 3 (1990), p. 45.

81 MacGaffey, "Fetishism Revisited", p. 172. O termo "fetiche" deriva da palavra portuguesa "feitiço". Ao que parece, o termo começou a ser usado na Costa do Ouro, mas logo foi exportado e aplicado pelos viajantes na vizinha Costa dos Escravos. Como elucida Luis Nicolau Parés, o conceito de "fetiche" se referia tanto ao "ídolo" (materialidade) quanto ao culto (imaterialidade). Cf. Luis Nicolau Parés, O rei, o pai e a morte: a religião vodum na antiga Costa dos Escravos na África Ocidental, São Paulo: Companhia das Letras, 2016, pp. 30-36. O “fetiche”, em termos técnicos, pode ser definido como o objeto que possui poderes mágicos em si mesmo ou que contenha alguma substância mágica. Frank Willett, Arte africana, São Paulo: Edições Sesc São Paulo, 2017, p. 291. Desde fins do século XV, cronistas e viajantes portugueses registraram o uso de "ídolos” e "fetiches” no continente africano; primeiro, na África Ocidental e, posteriormente, na África Central. Pacheco Pereira, por exemplo, em Esmeraldo de situ orbis (1506-1508), definiu os africanos do delta do Níger como “idólatras” - embora não descreva os “ídolos” que estes povos veneravam. Sobre 
Coube, porém, ao antropólogo Edward B. Tylor (1832-1917) estabelecer a definição clássica de fetichismo, que ele considerava como uma "doutrina de espíritos incorporados, anexados ou transportando a influência sobre certos objetos materiais (incluindo a adoração de pedras, ossos etc.)” ${ }^{82}$ Em 1938, o missionário etnógrafo Van Wing observou que a associação fetichismo-idolatria de Tylor é totalmente alheia à concepção nativa bantu, "não havendo nkisi-árvore e nkisi-planta”. ${ }^{83}$ Com efeito, os bantu nunca sobrepuseram um nkisi a um objeto natural. Como advertiu MacGaffey, os minkisi são objetos rituais fabricados, enredando-se em uma complexa tradição de preparação (personificação), que os colocava em relação com o espírito/entidade e os praticantes do ritual. ${ }^{84}$

As denúncias contra Catarina Juliana revelam que os minkisi, venerados pela sua sociedade religiosa, eram colocados em "certa casa”. ${ }^{85}$ A maior parte das testemunhas ouvidas no processo utilizaram a expressão “casa”, que parece se referir ao templo/altar de culto onde os minkisi eram colocados. Uma testemunha, porém, sugere que eles eram guardados em uma casa apenas após as cerimônias de veneração. ${ }^{86}$ No Reino do Congo, “os ‘ídolos’ e as ‘casas dos ídolos’ eram, provavelmente, altares

o Benim, escreveu: "Há muitos abusos no estilo de vida desta gente, seus fetiches e idolatrias”. Pacheco Pereira, Esmeraldo de situ orbis, Bissau: Centro de Estudos da Guiné Portuguesa, 1956, p. 132 e p. 134. Em fins do século XV, o cronista português Rui de Pina, a respeito do Reino do Congo, relatou que o mani soyo, após converter-se ao catolicismo, "ordenou que se queimasse todos os fetiches e, possivelmente, as imagens dos ancestrais" - Alberto da Costa e Silva, A manilha e o libambo: a África e a escravidão, de 1500 a 1700, Rio de Janeiro: Nova Fronteira, 2011, p. 363.

82 Edward B. Tylor, Primitive Culture, Boston: Estes \& Lauriat, 1874, v. 2, p. 144.

83 J. Van Wing, Etudes Bakongo, Brussels: Desclée de Browner, 1959, p. 383.

84 MacGaffey, “Fetishism Revisited”, pp. 172-173; e “The Personhood”, p. 50.

85 ANTT, TSOIL, DA, cx. 1580, cód. 13839, Correspondência de Catarina Juliana, fls. 15v, 23-28. Vide o depoimento de Dapper sobre "casa de deuses" ou altares construídos sob o beiral das moradias, com o formato de pequenas casas de cerca de vinte centímetros de altura, onde eram deixados alimento e bebida em: Dr. O. Dapper, Naukeurige Beschrijvinge der Afrikaensche Gewesten van Egypten, Barbaryen, Libyen, Biledulgerid, Negroslant, Guinea, Ethiopiën, Abyssinie..., Amsterdã: Jacob van Meurs, op de Keyfersgracht, in de Stadt Meurs, 1668, p. 170.

86 ANTT, TSOIL, DA, cx. 1580, cód. 13839, Correspondência de Catarina Juliana, fl. $39 \mathrm{v}$. 
para divindades territoriais, chamadas de kiteki e servidas por sacerdotes chamados nganga kiteke, análogo do termo quimbundo utilizado por Cavazzi e outros". ${ }^{87}$ No processo de Catarina Juliana, os altares e os sacerdotes responsáveis pelo culto não são assim nomeados devido à origem ambunda (e não quiconga) dos implicados nas denúncias.

Os minkisi mantidos na casa do capitão-mor não parecem ter constituído santuários territoriais centrais, como os que John K. Thornton descreve em seu estudo sobre a religião e a vida cerimonial no Congo e na área ambundu. Contrapartes deles, porém, eram aparentemente depositadas no interior de residências de homens importantes, em casinhas de madeiras ou no interior de residências - provavelmente para não tornar público um “culto gentílico” dentro de um presídio português. Aventamos que as “casas” dos minkisi tenham sido colocadas na residência do capitão-mor porque, “em algumas áreas [bantu], nenhum oficial de Estado poderia ser empossado sem o consentimento de um desses seres por meio do kitomi [sacerdote que prestava culto aos kitekes (termo quicongo) ou divindades]". ${ }^{88}$ Ainda que os espíritos cultuados pelos kitomi fossem territoriais e da natureza (sobretudo, das águas), distintos, portanto, dos minkisi - que se manifestavam em/incorporavam estatuetas e objetos ${ }^{89}$ - é possível que João Pereira da Cunha, durante o seu provimento como capitão-mor do presídio de Ambaca, tenha realizado rituais privados em homenagem a entidades africanas. Sob essa ótica, rituais africanos de provimento passaram da antiga condição pré-colonial de oficiais (públicos) para a de periféricos (privados).

Um manuscrito de 1747, localizado na Biblioteca Cívica de Turim, que narra expedições de capuchinhos italianos para o Reino do Congo, traz uma aquarela da década de 1740 em que observamos uma “casa de ídolo” sendo queimada por um dos missionários. Como se vê na

87 Thornton, “Religião e vida cerimonial”, pp. 88-89.

88 Thornton, "Religião e vida cerimonial”, p. 89.

89 Sobre as diferenças entre os espíritos cultuados pelos kitomi e os minkisis, Cf. Anne Hilton, The Kingdom of Kongo, Oxford: Oxford University Press, 1985. 
figura abaixo, essas casinhas eram de baixa altura (cerca de pouco mais de um metro), possuindo apenas uma porta, na fachada, com formato retangular, telhado de palha e, provavelmente, paredes de argila sustentadas por madeiras e caiadas, em imitação às habitações humanas e muito semelhantes aos mocambos que os negros bantu construíam no Brasil colonial. ${ }^{90}$ Os “ídolos” eram depositados no interior dessas casinhas. Na aquarela, observamos um missionário capuchinho atear fogo com uma tocha na "casa de fetiche” e, na frente da casa, "ídolos” e "objetos-fetiche” usados pelos “mágicos” (serpentes, cabeças de cabra, garras etc.).

Figura 1

Sacerdote católico queimando casa de ídolo (Sogno, Reino do Congo, 1740)

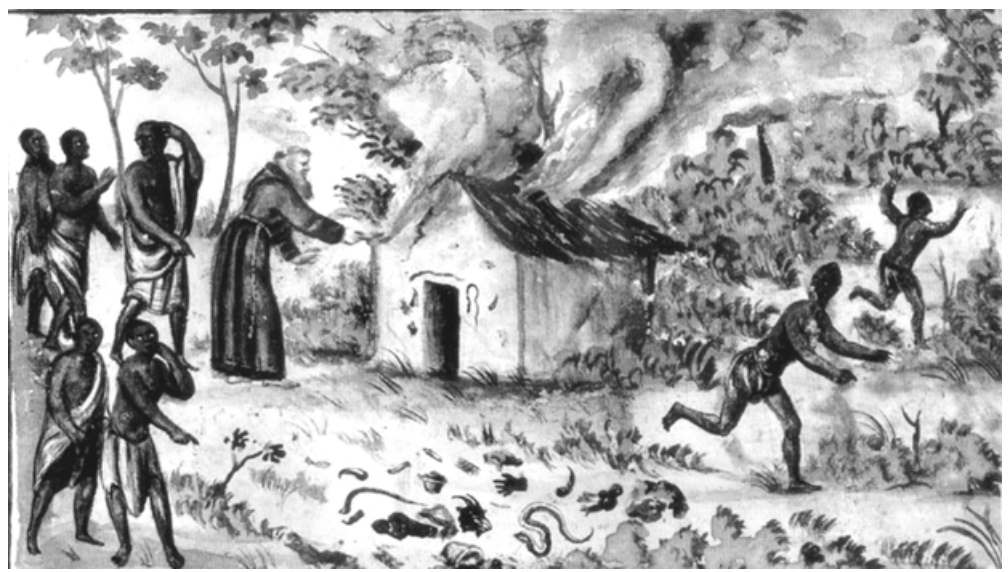

Fonte: Paola Collo e Silvia Benso (eds.), Sogno: Bamba, Pemba, Ovando e altre Contrade dei Regni di Congo, Angola e adjacenti, Milão: publicado privadamente por Franco Maria Ricci, 1986, p. 163.

"Festas e bailes na forma de cerimônias" eram realizadas por Catarina Juliana e pelos seus sócios a título de "culto e veneração"

90 Vide a aquarela "Habitações de negros” (1835) em: Johann Moritz Rugendas, Viagem pitoresca através do Brasil, São Paulo: Círculo do Livro, 1978, fig. 40. 
a objetos-minkisi. ${ }^{91}$ Estes eram: Gangazumba, Quibuco e Mutacalambo. ${ }^{92}$ As estatuetas-minkisi foram trazidas "de casa de certos mágicos donde estavam depositados”, sendo, portanto, fabricadas e personalizadas nos sertões, antes de serem colocadas no templo (“casa”) anexo à morada de Catarina Juliana, no presídio de Ambaca. ${ }^{93}$ Uma das testemunhas do processo revelou que as estatuetas eram "de pau” (madeira) e foram fabricadas por um "mágico do sertão" (nganga) chamado Dalla a' Quipaquina. ${ }^{94}$ As entidades cultuadas pela sociedade religiosa de Catarina Juliana possuíam representações materiais antropomórficas, mas não correspondiam à aparência da entidade e, sim, ao seu atributo ou poder ou seja, “ao que o nkisi faz”. ${ }^{95}$ Wyatt MacGaffey e J. M. Janzen ressalvam que os minkisi também poderiam ser produzidos com chifres de animais, ossos e sacos de couro, mas eram, geralmente, talhados em madeiras. ${ }^{96}$

Entre as sociedades africanas, o ato de entalhar estatuetas era rodeado de rituais. Em algumas sociedades, antes mesmo dos rituais de personificação da estatueta, realizavam-se ritos de apaziguamento dos espíritos que habitavam as árvores que forneciam a matéria-prima. ${ }^{97}$ Como assinala Albert De Surgy: um objeto de culto

não se torna funcional até o momento em que um tratamento ritual apropriado o faça perder seu estatuto de objeto para transformá-lo em um componente suplementar da pessoa que o adquire. Não obstante sua

91 ANTT, TSOIL, DA, cx. 1580, cód. 13839, Correspondência de Catarina Juliana, fl. 11.

92 ANTT, TSOIL, DA, cx. 1580, cód. 13839, Correspondência de Catarina Juliana, fls. 15v, 22, 28v, 38, 38v, 39v.

93 "Esses altares eram frequentemente instalados nas casas ou em conjunto de edifícios" - Thornton, "Religião e vida cerimonial”, p. 87.

94 ANTT, TSOIL, DA, cx. 1580, cód. 13839, Correspondência de Catarina Juliana, fl. 103.

95 MacGaffey, “The Personhood”, p. 55.

96 Wyatt MacGaffey e J. M. Janzen, “Northern Kongo Ancestor Figures”, African Arts, n. 28 (1995), p. 87.

97 Willett, Arte africana, p. 179. 
localização e sua forma material, ele não é mais um objeto no sentido usual do termo e não deve ser apreendido como tal..$^{98}$

Uma vez personificadas, as estatuetas tornavam-se minkisi, adquirindo vida - agindo, às vezes, inclusive, de forma autônoma. Para além dos ancestrais, existiam diversas entidades e espíritos que personificavam as estatuetas. As energias que esses objetos rituais tinham se somavam a outras, borrando as fronteiras entre elas. Como veremos, os mesmos espíritos que habitavam essas estatuetas-minkisi também "vinham à cabeça” das pessoas, não havendo, portanto, uma clara diferenciação entre os banganga, os objetos rituais e as forças invocadas. Mas o que era - e como se dava - a personificação de uma estatueta? As estatuetas (como as cabaças, trouxas e outros objetos) eram apenas “recipientes” dos minkisi e não possuíam vida até que forças espirituais fossem incorporadas a elas. Essas forças eram emanadas de seres que habitavam o mundo dos mortos e pertenciam a quatro classes: “ancestrais (bakulo), espíritos locais (bisimbi, bankita), fantasmas (minkuyu) e aqueles que voluntariamente não estavam presentes em objetos-minkisi (feiticeiros e bruxas)" ${ }^{99}$

Cabia aos banganga principais fabricar os minkisi de sua sociedade religiosa, estendendo os poderes dos espíritos cultuados aos novos banganga por meio de rituais de iniciação - tal como ocorreu, como vimos, com Catarina Juliana, que foi iniciada por Esperança Cazolla, uma nganga mestra. Durante os rituais de iniciação, o nganga principal fazia uma viagem ao mundo dos mortos, trazendo a entidade invocada para a estatueta - que, por essa via, se tornava um objeto-nkisi. Desse modo, o nkisi era um objeto ritual original, criado pelo nganga principal, que substituía a entidade habitante do mundo dos mortos, personalizando os seus poderes. Forças do além, conjuradores, iniciandos e objetos rituais personificados formavam um continuum hierarquizado,

98 Albert De Surgy, Nature et Fonction des Fétiches en Afrique Noire, Paris: L’Harmattan, 1994, p. 84.

99 MacGaffey, “The Personhood”, p. 49. 
estando indissoluvelmente imbricados segundo uma ordem cosmológica. De acordo com MacGaffey:

Esta manifestação material do nkisi corresponde a uma hierarquia de pessoas: a força ancestral corporificada no objeto original; o nganga fundador; o nganga principal presente (ngud a nganga); o nganga júnior ou noviço; o paciente ou eventual beneficiário do tratamento. Esta hierarquia exemplifica a sequência "instituição, sucessão, performance” característica dos poderes mágicos em todas as religiões. ${ }^{100}$

O nkisi refere-se, assim, a todos os elementos da hierarquia que estavam presentes durante a sua composição ou ativação - o que chamamos aqui, baseados em MacGaffey, de “personalização”. Como se vê, a cosmologia bantu define o objeto-nkisi de uma forma muito mais complexa do que a noção de "ídolo”, usada pelos inquisidores portugueses: não se trata da adoração a um "objeto mágico”, mas a um objeto que, devidamente ativado e personalizado, tem para si transferidos poderes da entidade que o personalizou. O objeto nkisi não era “adorado” isoladamente, mas inscrito em uma hierarquia ritual que o ligava a pessoa iniciada-curada e ao nganga principal, responsável pela fixação de poderes da entidade na estatueta.

A ativação do objeto-nkisi se dava pelo seu preenchimento com componentes medicinais, chamados de bilongo pelos bacongo e povos vizinhos. Sem esses "remédios", as estatuetas eram mera materialidade, sem poderes. A ativação do nkisi passava pela agência ritual do nganga principal, que, como ressaltamos, trazia a entidade do mundo dos mortos e aprisionava-a na estatueta. Antes de invocar os poderes do além, era necessário incluir, na estátua, dois tipos de objetos: metafóricos e metonímicos. Os elementos metafóricos consistiam em partes de vegetais, minerais e animais que qualificavam o poder da entidade invocada - tais como o pó

100 MacGaffey, “The Personhood”, p. 50. 
de ervas e azeites de carrapato, elementos metafóricos de Gangazumba, objeto-nkisi de Catarina Juliana. Já os elementos metonímicos eram vestígios materiais - reais ou simbólicos - da força invisível, como, por exemplo, a terra da sepultura de um morto invocado. ${ }^{101}$ Juntos, esses dois tipos de elementos faziam com que "os espíritos dos mortos [e entidades fossem] metonimicamente presos em uma armadilha metafórica”. ${ }^{102}$

As testemunhas ouvidas no processo aqui analisado revelam que essas entidades/espíritos, quando invocados, também passavam a habitar as cabeças dos seus iniciados por meio de uma conjunção com os objetos-minkisi-afinal, como assinalamos, banganga e objetos-minkisi formavam um continuum. Holisticamente, os rituais identificavam o objeto-nkisi com o seu nganga (original ${ }^{103}$ ou iniciado) por meio da recapitulação dos elementos metafóricos em sua pessoa. Os poderes permanentemente avivados no objeto ritual a partir da sua personalização eram estendidos, mediante invocação, para o seu sacerdote oficiante e iniciandos. O espírito/ entidade, capturado no além e encapsulado no objeto ritual, também se metia na cabeça dos seus sacerdotes, que, assim, passavam a ser também recipientes-esconderijos dessas forças invisíveis.

A entidade que Catarina Juliana "consentia que lhe viesse à cabeça”"104 era Gangazumba. Embora não desejemos projetar, retrospectivamente, para o século XVIII os inquices ${ }^{105}$ cultuados atualmente no

$101 \mathrm{O}$ espírito do morto era, assim, incorporado à terra de sua sepultura e parte dos seus poderes era aprisionada no objeto-nkisi.

102 Wyatt MacGaffey definiu estes elementos que compunham os minkisi a partir das considerações de De Heusch. Cf. MacGaffey, “Fetishism Revisited”, p. 174.

103 "Criador" do objeto nkisi.

104 ANTT, TSOIL, DA, cx. 1580, cód. 13839, Correspondência de Catarina Juliana, fls. $18 \mathrm{v}, 23 \mathrm{v}, 29 \mathrm{v}, 39 \mathrm{v}$. No verso da folha 29, os inquisidores revelam que uma das acusações que pesava sobre a ré era a de que ela "consente a que este [demônio] lhe viesse à cabeça, [...] sendo ela reconhecida e tratada por Xingaladra ou possuidora do ídolo chamado Gangazuba, da mesma sorte que o eram de outros ídolos outras certas pessoas [de sua sociedade religiosa]".

105 "No Candomblé brasileiro de rito Angola (diretamente relacionado a povos de língua bantu) a palavra inquice, derivada de nkisi, é sinônimo de orixá (palavra mais comum nos ritos nagô), isto é, refere-se primariamente a divindades invisíveis, e não a suas atualizações materiais. Este deslizamento de sentido aponta para ambivalências 
Brasil, convém assinalar que uma entidade homônima a essa é cultuada em terreiros de candomblé angola de Salvador. Neles, Gangazumba (também chamado de Mameto Zumbá, Zumbanganga e Zumbá) ${ }^{106}$ detém a “energia dos pântanos, dos manguezais, da lama original que ao endurecer formou a terra; é a grande senhora da morte e do renascimento”. ${ }^{107}$ Se as propriedades da entidade eram as mesmas em meados do século XVIII, Catarina Juliana receberia, em sua cabeça, aquele que era "considerado o nkisi mais velho, a origem dos demais minkisi". ${ }^{108}$ Como "filha"109 do "nkisi ancestral”, a que todos prestam reverência, Catarina certamente ocupava uma posição distinta na sua sociedade religiosa. Em carta trocada em 14 de maio de 1656 com o missionário capuchinho Giovanni Antonio Cavazzi, Serafino de Cortona notou que Gangazumba era um dos deuses "mais estimados" da região ambundu, considerado um dos "guardiões do Ndongo, e tinha casas especiais a ele dedicadas". ${ }^{110}$

Quanto aos demais “ídolos” referidos no processo, eles correspondiam às entidades que "vinham às cabeças” dos "sócios” de Catarina

contidas em religiões de matriz africana em geral” - Rogério Brittes Wanderley Pires, "O conceito antropológico de fetiche: objetos africanos, olhares europeus", Dissertação (Mestrado em Antropologia Social), Universidade Federal do Rio de Janeiro, Rio de Janeiro, 2009, p. 116.

106 Yeda Pessoa de Castro afirmou que essa divindade é geralmente chamada de “Lemba”. Yeda Pessoa de Castro, Falares africanos na Bahia: um vocabulário afro-brasileiro, Rio de Janeiro: Topbooks, 2001, p. 264.

107 "As cores de suas roupas e colares é o roxo, em algumas, casas, mesclado com branco" - Elizabete Umbelino de Barros, "Línguas e linguagens nos candomblés de nação Angola”, Tese (Doutorado em Linguística e Semiótica), Universidade de São Paulo, São Paulo, 2007, p. 275.

108 Valéria Amim, “Águas de Angola em Ilhéus: um estudo sobre construções identitárias no candomblé do sul da Bahia”, Tese (Doutorado em Cultura e Sociedade), Universidade Federal da Bahia, Salvador, 2009, p. 214.

109 Às vezes, em uma nítida inversão estrutural, os nkisis (estatuetas) são chamados de “filhos” daqueles que os recebem e os veneram. ANTT, TSOIL, DA, cx. 1580, cód. 13839, Correspondência de Catarina Juliana, fls. 99-99v.

110 "Serafino da Cortona a Giovanni Antonio Cavazzi”, 14 maio 1656 in António Brásio (ed.), Monumenta Missionaria Africana, Lisboa: Agência-Geral do Ultramar, 1952-1988, v. 12, p. 24; uma versão um pouco diferente, datada de 2 de maio, é encontrada em Cavazzi, Missione evangelica nel regno de Congo, v. B, 1668, pp. 452-453. 
Juliana. ${ }^{111}$ Quibuco (Kibúku), entidade “que estava na cabeça” de uma negra chamada Luzia, ${ }^{112}$ é o nkisi da ventura, da sorte e da felicidade. ${ }^{113}$ Raimundo José da Cunha Matos, em seu Compêndio histórico das possessões de Portugal na África (1848), se refere a ele como "deus das riquezas”. ${ }^{114}$ De acordo com Ismael Girotto, essa entidade ainda é cultuada nos candomblés de nação angola. ${ }^{115}$ Quibuco é invocado para a cura de enfermidades e suas oferendas são "emcombas e galinhas”. Outro nkisi mencionado no processo, Mutacalambo (Mutakalambo), "deus da caça, protetor dos caçadores”, ${ }^{116}$ se metia na cabeça do escravo Teodósio. ${ }^{117}$ Assim como Gangazumba e Quibuco, Mutacalambo é cultuado nos terreiros de candomblé de nação angola. Seus atributos são o "arco e flecha”"118 (Figura 2). Na sociedade religiosa de Catarina Juliana, “objetos rituais dedicados a Mutacalambo incluíam, ainda, uma macua (concha de cabaça) e uma cauda de búfalo”. ${ }^{119}$ Oscar Ribas refere-se a esse nkisi como "supervisor dos animais aquáticos”. ${ }^{120}$ Como Gangazumba e Quibuco eram incorporados por sacerdotisas e duas das entidades citadas acima habitavam águas terrestres, parece certo que os minkisi da sociedade

111 ANTT, TSOIL, DA, cx. 1580, cód. 13839, Correspondência de Catarina Juliana, fls. $18 \mathrm{v}, 29 \mathrm{v}$ e $39 \mathrm{v}$.

112 ANTT, TSOIL, DA, cx. 1580, cód. 13839, Correspondência de Catarina Juliana, fl. $104 \mathrm{v}$.

113 Assis Júnior, Dicionário kimbundu-português, p. 115.

114 Raimundo Cunha Matos, Compêndio histórico das possessões de Portugal na África, Rio de Janeiro: Arquivo Nacional, 1963.

115 Ismael Giroto, “O universo mágico-religioso negro-africano e afro-brasileiro: banto e nàgó”, Tese (Doutorado em Antropologia), Universidade de São Paulo, São Paulo, 1999, p. 282.

116 Assis Júnior, Dicionário kimbundu-português, p. 320.

117 ANTT, TSOIL, DA, cx. 1580, cód. 13839, Correspondência de Catarina Juliana, fl. $104 \mathrm{v}$.

118 Anselmo José da Gama Santos, “Terreiro Mokambo: espaço de aprendizagem e memória do legato bantu no Brasil”, Dissertação (Mestrado em Educação e Contemporaneidade), Universidade do Estado da Bahia, 2008, p. 94.

119 Kananoja, “Healers, Idolaters, and Good Christians”, p. 453.

120 Óscar Ribas, “Ilundu: espíritos e ritos angolanos”, Museu de Angola, 1958, p. 41. 
religiosa de Catarina Juliana eram dos chamados domínios "de baixo", ou seja: femininos e benevolentes. ${ }^{121}$

\section{Figura 2}

Estatueta do fetiche Malongo, dos congos

(correspondente ao Mutacalambo, dos angolas)

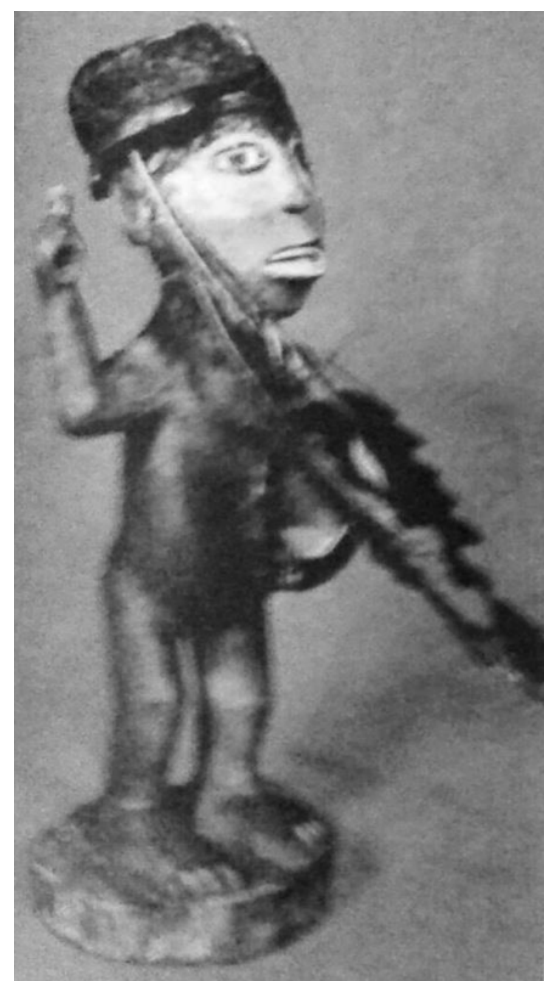

Fonte: Manchester Museum. Altura 27 cm apud Willet, Arte africana, p. 181, fig. 167.

A escultura acima é do nkisi Malongo dos congos, entidade correspondente ao Mutacalambo dos angolas. Na estatueta, “o material do

121 Esses se diferenciavam dos minkisi “de cima”, viris e violentos. Os sacerdotes dos últimos eram os nganga nkandi, sempre do sexo masculino. Cf. MacGaffey, "The Personhood", p. 50. 
abdômen é coberto por um espelho importado, ao passo que outra porção dele foi moldada em um chapéu. Os olhos são cobertos de vidro. A mão direita, erguida, empunhava anteriormente uma arma”, ${ }^{122}$ provavelmente uma flecha. Sem o "material do abdômen", as estatuetas não têm poder algum. São - em língua quicongo - apenas teke (objetos vazios, mera materialidade). Se elas são, contudo, preenchidas com plantas, barros, sangue, pedaços de animais, canções, palavras, pregos etc., tornam-se minkisi, servindo de recipiente para os espíritos. Como vimos, os minkisi eram “composições de espírito, objeto e ingredientes variados” 123 - espírito e matéria eram indissociáveis nesses objetos rituais. O próprio nganga não era apenas um manipulador favorecido pelo nkisi, mas parte de seu aparato material. ${ }^{124}$ De fato, os rituais aqui descritos "aparentemente negligenciam ou parecem repelir distinções entre espíritos (invisíveis, animados), objetos de culto (visíveis, animados) e pessoas (visíveis, animadas), insistindo, pode-se dizer, na comunidade entre os três"; ${ }^{125}$ é o que chamamos de continuum objeto-pessoa-divindade.

A personificação dos objetos-minkisi também envolvia aspectos externos a eles. Os banganga que invocavam forças invisíveis por meio deles deveriam tratá-los como "pessoas", sendo gentis ou servis, ${ }^{126}$ conversando e, não raro, provocando e gerando raiva. Provocar as forças espirituais era uma forma de fazê-las agir de acordo com os motivos da invocação: cura, adivinhação ou reversão de feitiços. Uma forma de provocar a ira das divindades invocadas e obter eficácia ritual era ofendê-las e cravá-las com pregos. A conexão metonímica externa se dava pela inclusão de partes do corpo (unhas, cabelos etc.) da pessoa a

122 Willett, Arte africana, p. 181, fig. 167.

123 Pires, “O conceito antropológico de fetiche”, p. 166.

124 MacGaffey, “The Personhood”, p. 55.

125 MacGaffey, "Fetishism Revisited”, p. 178.

126 De fato, Catarina Juliana e seus sócios "punham-se de joelhos e falavam com palavras submissas e reverentes” com os seus minkisi. ANTT, TSOIL, DA, cx. 1580, cód. 13839, Correspondência de Catarina Juliana, fl. 15. 
ser curada ou do feiticeiro/bruxa que provocou o malefício. ${ }^{127}$ Por vezes, como salienta William Pietz, o nganga e/ou seu cliente tinham que ingerir parte do nkisi para fazê-lo atuar. Este era um traço adicional do ritual que garantia a continuidade entre nganga, cliente, nkisi, espírito e, até mesmo, feiticeiro/bruxa. ${ }^{128}$

A acusação e os depoimentos do processo de Catarina Juliana arrolam, ainda, os “ídolos" "Tulariam Bandê”, "Alutá” e os gêmeos “Quitari Quia Cuvimba” e "Pingi”. Entretanto, como os próprios inquisidores constataram, por vezes, os nomes dos ídolos destoaram de testemunha para testemunha, sendo alguns deles "supostos [...], como Pingi e Tulariam Bandê, por não serem nomeados pelos contornos desta Cidade [de Luanda] e presídios”. ${ }^{129}$ Realmente, não encontramos qualquer menção a minkisi com esses nomes na literatura especializada nas religiões bantu, mas - como já conjeturamos - eles podem ter sido espíritos-guias cujos nomes e identidades os membros da sociedade religiosa de Catarina Juliana levaram por toda a vida. O caráter “suposto” deles pode, assim, decorrer do fato de terem sido "batizados” em línguas secretas, usadas em rituais análogos aos kimpasi praticados pela sociedade religiosa de Catarina Juliana. ${ }^{130}$

Tendo em vista a atuação de Catarina Juliana também como sacerdotisa curadora de doenças provocadas por antepassados (xinguila), pode ser ainda que esses “ídolos” não identificados fossem objetos rituais correspondentes ao kitekes congoleses; isto é, espécies de "bonecos curandeiros”. Diferentemente dos minkisi, eles eram possuídos exclusivamente pelos espíritos dos antepassados mortos dos consulentes. Salvaguardada essa diferença fundamental, o modus operandi devia ser bastante

127 MacGaffey, “The Personhood”, pp. 52-53.

128 Os feiticeiros e as bruxas, diferentes dos banganga, praticavam um "culto negativo," invocando "fantasmas anônimos, sem casa”. MacGaffey, "Fetishism Revisited", p. 180.

129 ANTT, TSOIL, DA, cx. 1580, cód. 13839, Correspondência de Catarina Juliana, fls. 153-154.

130 Slenes, “A árvore de Nsanda transplantada”, pp. 288-289. 
semelhante: tal como nos minkisi, os antepassados eram invocados para possuir a estatueta e "fornecer conselhos, remédios e outras coisas. De forma a facilitar a possessão, o adivinho fazia oferendas ao espírito, na forma de comida e bebidas alcoólicas”. ${ }^{131}$

Seja como for, estamos certos que Gangazumba, Quibuco e Mutacalambo eram invocados durante as cerimônias da sociedade religiosa de Catarina Juliana para serem consultados (adivinhação) e para promoverem curas. Após serem invocados e se manifestarem nos seus médiuns, os consulentes recebiam "respostas dos mesmos sobre o que pretendiam saber e alcançar, ainda a respeito dos futuros contingentes, conseguindo por este meio a saúde nas enfermidades e fortuna avantajada nos negócios”. ${ }^{132}$ Como observou Rogério Pires:

Para cada conjunto de sintomas vistos como uma doença há ao menos um nkisi. O nkisi é o "mestre" de uma doença ou mal que domina conforme o necessário, podendo curá-la ou causá-la, seja a varíola, a loucura, um veneno, pragas de insetos etc. O domínio de operação de cada nkisi corresponde à sua função, quase sempre relacionada à morte e ao sofrimento, cura ou retribuição de um mal. Tomados em conjunto, os minkisi expressam a experiência da vida no Congo, os perigos mais frequentes encontrados pelos bacongo [e povos vizinhos] e com os quais eles tinham de lidar. ${ }^{133}$

Os bacongo do Reino do Congo, estudados por MacGaffey - como os ambundus do Reino de Angola -, viam os minkisi como respostas aos problemas que os afligiam; os minkisi eram indissociáveis, portanto, da cura. Na concepção dos povos bantu, a cura se dava mediante uma relação com um nkisi, contemplando, ao mesmo tempo, aspectos históricos e

131 James Sweet, Recriar África: cultura, parentesco e religião no mundo afro-português (1441-1770), Lisboa: Edições 70, 2007, p. 186.

132 ANTT, TSOIL, DA, cx. 1580, cód. 13839, Correspondência de Catarina Juliana, fls. 22-22v.

133 Pires, “O conceito antropológico de fetiche”, p. 114. 
míticos. Por essa ótica, a cura de uma doença real era explicada ritualmente pela resolução de dilemas cósmicos nos quais a entidade curadora encontrava-se enredada segundo a mitologia bantu. Os doentes procuravam um nganga (sacerdote curandeiro) e, em casos mais graves, através de um processo de iniciação (que envolvia rituais mais complexos), tornavam-se assistentes ou nganga do nkisi que o curou. Como vimos, esse foi o caso de Catarina Juliana. Demandando a sua iniciação, Gangazumba provocou uma enfermidade em Catarina Juliana, que, por meio do ritual realizado por Esperança Cazolla, sua mentora, passou da condição de pessoa curada à de iniciada no culto, tornando-se, assim, uma agente de cura (nganga) que mediava os poderes da entidade que se metia na sua cabeça.

Para além dos minkisi guardados na “casa” de culto do capitão-mor de Ambaca, outras estatuetas - das mesmas divindades que lá se encontravam - foram enterradas pelos membros da sociedade religiosa de Catarina Juliana "na vivenda das mesmas casas". ${ }^{134}$ Como aponta Pietz, devido à sua materialidade, os minkisis eram territorializados - ou seja, fixados a espaços materiais específicos (lugar geográfico, parte do corpo, estatueta etc.). ${ }^{135}$ Nesse sentido, o minkisi é sempre histórico e contextual, possuindo ainda a reificação como seu atributo, já que ele torna valores abstratos em coisas concretas; assim, à personalização do nkisi se somavam a territorialização, a historicização e a reificação.

\section{“No campo, entre as árvores a que chamam imbondeiros"}

Além de ter sido acusada de adorar “ídolos” na casa do capitão-mor João Pereira da Cunha, Catarina Juliana também foi denunciada por adorá-los

134 ANTT, TSOIL, DA, cx. 1580, cód. 13839, Correspondência de Catarina Juliana, fls. 19-30.

135 William Pietz, “The Problem of the Fetish”, Anthropology and Esthetic, n. 9 (1985), p. 15. 
"fora do presídio, no campo, entre as árvores a que chamam imbondeiros (baobás)”. Nessas ocasiões, Catarina Juliana se associava secretamente a outros moradores do presídio de Ambaca e a escravos do mesmo capitão-mor para realizar "adorações, consultas ou sacalamentos". ${ }^{136}$ Tais rituais eram presididos por "mágicos" que moravam nos sertões de Angola. Esse foi o caso do preto Dalla a' Quipaquina e de Antônio Cambundo, que acompanhavam as cerimônias religiosas fora do presídio de Ambaca. ${ }^{137}$

Essas cerimônias realizadas em campo aberto, apartadas dos núcleos urbanos de Angola, podem ter sido cerimônias realizadas para reeditar a eficácia dos rituais fúnebres chamados entambe (estambe, tambi) ${ }^{138} \mathrm{O}$ governador de Angola Sousa Coutinho, em 1766, relatou que muitos habitantes do reino viviam "só no vício do gentilismo qual é o de saírem da capital para fazerem o entambe nos arrimos do campo". ${ }^{139}$ Durante os rituais, um animal (boi, carneiro ou cabra) era imolado para ser consumido em meio ao choro dos parentes vivos. É possível que o bode (ou cabra) citado no processo de Catarina Juliana tivesse essa finalidade, mas é mais provável que ele fosse adorado como uma entidade, já que há indícios de que os banganga do sertão angolano orientavam seus consulentes, iniciados nesses rituais, a adorarem um bode para se curarem de doenças. Pessoas eram levadas à consulta dos banganga sobretudo após adoecerem, mas também por sonharem com parentes mortos. O governante ambundu Kakulu Ka Kahenda, em informação dada ao jesuíta Manuel Ribeiro, em 1672, afirmou que, segundo a crença das populações

136 Os escravos do capitão-mor eram, como se viu, a parda Josefa e o “molecão” Teodósio. Além destes, Felipe Dias Chaves também foi apontado como sócio nessas cerimônias. ANTT, TSOIL, DA, cx. 1580, cód. 13839, Correspondência de Catarina Juliana, fls. 103-103v.

137 ANTT, TSOIL, DA, cx. 1580, cód. 13839, Correspondência de Catarina Juliana, fls. 103-103v.

138 "Hoje é possível assistir a essas cerimônias fúnebres em Luanda, onde recebem o nome de Komba, ou komba-kia-toko". Pantoja, "Inquisição, degredo e mestiçagem”, p. 124.

139 AHU, Angola, cx. 50, doc. 63, Governador Sousa Coutinho, 1766. Citado por Pantoja, “Inquisição, degredo e mestiçagem”, p. 124. 
locais, "sonhar com os mortos impelia os vivos a fazerem sacrifícios e outros atos de adoração". ${ }^{40}$

Muitas vezes, o diagnóstico dos banganga era de quilundo [kilundu] ou zumbi [nzûmbi] - isto é, a doença seria causada pela negligência dos consulentes para com os seus parentes mortos - o que o antropólogo Victor Turner chamou de rito de aflição. Prescrevia-se, portanto, um rito que revalidasse o ritual de funeral (entambe) para apaziguar a alma do parente morto e restabelecer o equilíbrio (força vital) perdido. A alma do parente morto que vagava sem sossego e causava infortúnios era chamada de zumbi "ou ndele, nome mais usado em Luanda. Segundo a crença zumbi, as almas, quando saem do mundo subterrâneo, caminham no ar, perdidas. Quando pretendem alguma coisa, manifestam-se em sonhos ou em rebeldes enfermidades”. ${ }^{141}$ Se os rituais realizados por Catarina Juliana e seus associados no campo, entre árvores de imbondeiros, se tratassem de ritos restituidores da eficácia dos entambes, pode ser que as cerimônias realizadas dentro da casa do capitão-mor e no campo estejam relacionados e façam parte de um mesmo ritual - pois, após a imolação de um animal no campo, fazia-se uma festa na casa daquele que se curava, com batuques e com um mestre de cerimônia vindo do sertão angolano.

Cavazzi notou que, em Angola, "os mortos estavam cuidadosamente enterrados em cemitérios localizados em florestas fechadas ou distantes de áreas habitadas para que a alma pudesse ter o "máximo de descanso", além de permanecer serenamente em seu túmulo sem incomodar os vivos". ${ }^{142}$ Assim, os campos visitados por Catarina Juliana e seus consortes tratavam-se, provavelmente, de túmulos de antepassados

140 Manuel Ribeiro, “Carta da Missão que fizeram o p. Manoel Ribeiro e o irmão Francisco Correa, mandados pelo p. Antonio de Sousa, reitor que então era do Colégio de Angola, ano de 1672 para o de 1673 (15 de janeiro de 1674)” in Brásio (ed.), Monumenta missionaria africana, v. 3, p. 262.

141 Pantoja, “Inquisição, degredo e mestiçagem”, p. 124; Ribas, Dicionário de regionalismos angolanos, Lisboa: Contemporânea, 1997, p. 307.

142 João Giovanni Antonio Cavazzi, Descrição histórica dos três reinos do Congo, Matamba e Angola, Lisboa: Junta de Investigação do Ultramar, 1965, v. 1, p. 250 citado por Thornton, “Religião e vida cerimonial”, pp. 90-91. 
dos consulentes acometidos por doenças. As árvores de imbondeiros ou baobás eram, provavelmente, os locais em que os antepassados estavam assentados. Robert Farris Thompson advertiu que "vários observadores do século XVIII notaram que os congoleses e os seus descendentes na diáspora recorriam a garrafas para enganar e aprisionar espíritos malévolos”. ${ }^{143}$ Ainda que não saibamos se garrafas eram objetos disponíveis na Angola do século XVIII, o artifício de pendurá-las em árvores era recorrente entre os africanos da diáspora, "servindo para proteger as casas e as plantações da influência perniciosa de espíritos”. ${ }^{144}$ Os banganga utilizavam "as suas garrafas para revelar os espíritos maldosos que estavam na origem da doença do seu cliente”. ${ }^{145}$ James Sweet observou que, durante os rituais, a imagem do feiticeiro ou do espírito que causou o malefício aparecia no interior das garrafas penduradas nas árvores e, em se tratando do primeiro, os objetos roubados do cliente e que foram utilizados para realizar a feitiço. Com este ritual, o nganga desvendava a origem do infortúnio dos seus consulentes, assinalando os culpados.

Na Senegâmbia ou Alta Guiné, na África ocidental, os pais ou irmãos mais velhos que morriam eram levados pelos filhos ou irmãos até o pé de um baobá. A árvore da aldeia simbolizava o legado do pai morto, constituindo a árvore um lugar não ocupável pelos vivos, mas apenas pelos mortos e ancestrais. As sombras das árvores eram temidas, já que poderiam ser moradas de maus espíritos. ${ }^{146}$ Posto que no processo de Catarina Juliana não há referências a garrafas penduradas nas árvores para aprisionar espíritos causadores de malefícios, parece factível que os baobás da África central - como os da África ocidental - servissem de

143 Robert Farris Thompson, Flash of the Spirit; African and Afro-American Art and Philosophy, Nova Iorque: Vintage, 1984, pp. 142-145.

144 Sweet, Recriar África, p. 153.

145 Sweet, Recriar África, p. 153.

146 Marie-Cécile Ortigues e Edmond Ortigues, Édipo africano, São Paulo: Editora Escuta, 1989, pp. 79-82. 
morada a espíritos de ancestrais. ${ }^{147}$ Ainda que as testemunhas do processo falem em “entre as árvores”, e não “nas árvores”, me parece que os baobás (chamados imbondeiros, em Angola), mais do que o campo aberto, consistiam no marco fundamental de espacialidade dos rituais em questão. Essas árvores, de troncos enormes e espessos que podem chegar a nove metros de diâmetro, serviam, então, de moradas para os espíritos. Pela sua longevidade, o imbondeiro simbolizava a atemporalidade do mundo invisível, servindo, ainda, de fonte para a retirada de medicamentos. $\mathrm{Na}$ cosmologia ambundu, o imbondeiro aparece, pois, como lócus de conexão entre o mundo visível e o invisível.

Após esses rituais em campo aberto, entre os imbondeiros, a figura do xinguila - adivinho possuído por um espírito que fala por sua boca - era responsável por cuidar do bode no Dombé (Ndombé, luto em quimbundo). ${ }^{148}$ Segundo Cavazzi:

Eles adoram um ídolo que afinal, não passa de um bode vivo e grande, com pelo preto, barba comprida [...]. Deste bicho cuidam igualmente o xinguila e a sua mulher, os quais, por isso, são ambos chamados nganga-ia-nzumba. Os xinguila deste bode glorificam-se de predizer o futuro e de curar os doentes por meio dele, naturalmente acompanhando as cerimônias com invocações e sacrifícios. ${ }^{149}$

O doente mantinha esse bode, adorando-o nos momentos de aflição provocados por uma doença, tendo por finalidade apaziguar o espírito rebelde e obter a cura. No caso de Catarina Juliana e sua sociedade religiosa, o bode era adorado por ela que, como se viu, incorporava o nkisi Gangazumba. Catarina Juliana era também uma médium que recebia espíritos de antepassado com o objetivo de apaziguá-los, realizando a cura

147 Ressalvamos que, embora os cultos aos antepassados entre os ambundu estivessem associados aos imbondeiros, era, sobretudo, às árvores nsanda ou mulemba que eles se relacionavam. Cf. Slenes, “A árvore de Nsanda transplantada”, pp. 273-316.

148 Assis Júnior, Dicionário kimbundu-português, p. 31.

149 Cavazzi, Descrição histórica, v. 1, p. 210. 
dos seus consulentes. Em quicongo, esse tipo de sacerdócio era chamado de nganga-ia-nzumba, o que correspondia, em quimbundo, ao xinguila. Catarina Juliana atuou como xinguila durante a cura do capitão-mor João Pereira da Cunha, seu ex-senhor e amante. Em se tratando da cura de sua própria enfermidade, Catarina Juliana contou com o auxílio de uma sacerdotisa, nganga-nkisi e xinguila do sertão, a quem visitou em uma noite, conforme a sua confissão. Ela teria se iniciado nestas funções durante a sua cura. A busca da cura levava à iniciação do doente. No caso de Catarina, ela própria tornou-se nganga-nkisi e xinguila, recebendo em sua cabeça o nkisi Gangazumba e adorando o bode para a cura do capitão-mor. De consulente, converteu-se em sacerdotisa curandeira.

Cavazzi detalhou os rituais de possessão dos xinguila (médiuns de espíritos) no século XVII. De acordo com o missionário capuchinho, os xinguila eram extremamente numerosos e estimados entre os Imbangalas (Jagas), assim como entre outros povos angolanos. O ritual de possessão dos Imbangalas ocorria da seguinte forma:

O homem ou mulher põe-se no meio da multidão e ordena que todos the obedeçam, já que a sua função é promovida não pelo seu capricho, mas pelo impulso interior do espírito consultado. Entretanto, os músicos tocam os seus instrumentos e excitam os presentes com canções e gritaria apropriada [...]. Cantam algumas canções diabólicas com invocações, consideradas eficazes para persuadir o Diabo a entrar no corpo da pessoa. A pessoa, por seu lado, faz um juramento ao Diabo e convida-o a tomar posse dela. Ao som destes suplicantes, o Diabo dá-se à intervenção [...]. Então o feiticeiro levanta-se com muita seriedade, e permanecendo quieto por algum tempo, começa subitamente a agitar-se, movendo os olhos nas suas órbitas, atirando-se para o chão, contorcendo-se furiosamente, dobrando todos os seus membros [...]. O feiticeiro começa então a proferir palavras extravagantes, confusas e metafóricas, não sem antes ter avisado os presentes que estas não são as suas palavras, mas as palavras do espírito do Jaga falecido, 
cujo nome ele então assume, conservando [esse nome] até o fim da função [...]. Os Jagas dirigem-se a esta pessoa possuída porque julgam que ela sabe tudo o que se passa na outra vida, e usam das formas de respeito e reverência que usariam para com um semideus, interrogando-o e recebendo respostas como se ele fosse o espírito consultado. O possuído ameaça infortúnios, prediz contrariedades, pragueja, repreende a avareza de familiares, pede mais meios de subsistência, comidas, sangue humano e vítimas. ${ }^{150}$

Cavazzi retratou, em uma de suas aquarelas, xinguilas angolanos possuídos por espíritos de mortos (Figura 3). Os xinguilas, na aquarela original (colorida), têm tafetá vermelho à cintura e barro branco (mpemba) no corpo, acima das cinturas e nos braços. Ao receber o espírito, o xinguila pegava um machado (ver o xinguila com machado na mão ao fundo), ato que representava a conexão estabelecida com o espírito que tomava o seu corpo. A figura ajoelhada (soldado) era o consulente, o que explica, no caso do processo de Catarina Juliana e sua sociedade religiosa, o modo "submisso e reverente" com que os seus membros se prostravam diante dos espíritos consultados e das entidades adoradas.

150 Cavazzi, Descrição histórica, v. 1, pp. 204-205. O padre Caltanissetta descreve, de forma semelhante, os rituais de possessão dos nganga ngombo (médiuns de espíritos) do Congo. Cf. Luca da Caltanissetta, "Relatione della missione fatta nel regno di Congo per il padre Fra Luca da Caltanissetta per lo spatio di anni undici in circa sino all fine del 1701” in Romain Rainero (ed.), Il Congo agli inizi del settecento nella relazione di p. Luca da Caltanissetta, Florença: La Nuova Italia, 1972, pp. 254-255, 259-260. 
Figura 3

Xinguilas angolanos possuídos por espíritos de mortos (Angola, século XVII)

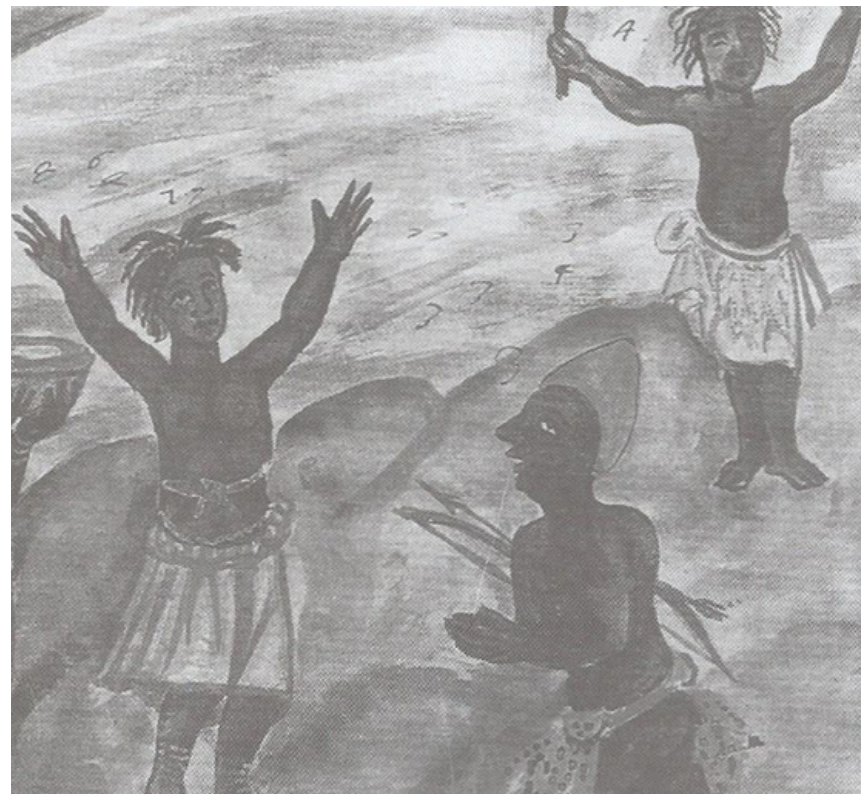

Fonte: Cavazzi, Manoscritti Araldi A, B, C: 1665-1666, 3 v., Modena: Carlo Araldi, 1969.

Para além de Catarina Juliana, encontramos nos “documentos avulsos" da Inquisição de Lisboa denúncias contra outras "negras xinguilas” que atuavam em Angola durante o século XVIII. O capitão-mor do Golungo, Francisco Gomes Pereira, por exemplo, foi denunciado em 1732 por superstições e feitiçarias. O denunciante afirmou que o capitão mandava "adivinhar por negros feiticeiros por panelas de loanzo”, tinha um "courozinho ou pele encantada para adivinhações breves”, venerava “ídolos” para "alcançar muitos impossíveis” e ser “afortunado” e, o que interessa aqui, tinha uma "negra sua escrava de nome Maria que [era] xinguiladora”. ${ }^{151}$ A relação entre o capitão-mor de Golungo e a sua “negra

151 ANTT, TSOIL, DA, cx. 1576, cód. 13615, Denúncias contra o capitão Francisco Gomes Pereira, 1732, fl. 1. 
xinguila” demonstra que o caso de Catarina Juliana não era uma exceção no reino de Angola.

A seguir, interpretaremos outros rituais ambundus realizados em campo aberto pela sociedade religiosa de Catarina Juliana: os chamados juramentos de bulungo.

\section{"Juramentos ambundus, a que chamam Bulungo"}

Catarina Juliana também se desdobrava, às vezes, em nganga mbulungu, pois foi acusada de, "em companhia de certas pessoas suas sócias, assistir com mágicos aos juramentos ambundus, a que chamam bulungo, a fim de certa pessoa da dita companhia saber quem dela falava e lhe pretendia fazer mal”. ${ }^{152}$ Bulungo [Mbúlungu], em quimbundo, significa tanto o "juramento" (jimbulungu) quanto a "bebida feita de vegetais eméticos e venenosos [...] triturados no kinu, vaso com pilão, [...] que o acusado bebe, só morrendo aquele em que recair a culpa”. ${ }^{153} \mathrm{O}$ ritual aplica-se, geralmente, a acusados de delitos graves, como o "enfeitiçamento de morte”. Se o acusado ingere a beberagem e vomita, ele é inocente, mas, "se, pelo contrário, foi ele o autor do crime, em terríveis convulsões aí mesmo sucumbe”. Os acusados que recusavam ingerir a droga, "quer por indução de alguns circunstantes, quer por sua própria vontade, sujeita-se ao pagamento de uma pesada indenização, e para que toda a gente saiba a sua ignomínia, o seu cabelo é cortado rente, em marcação de sinuosos quadriláteros”. ${ }^{154}$

Alexandre Marcussi notou que, em Angola, cerimônias semelhantes aos calundus coloniais "foram designadas pelos nomes de

152 ANTT, TSOIL, DA, cx. 1580, cód. 13839, Correspondência de Catarina Juliana, fls. 16-16v.

153 Assis Júnior, Dicionário kimbundu-português, p. 104, 135. O “indivíduo que nas cerimônias do juramento ministra o mbulungu ao paciente" era chamado, de acordo com Assis Júnior, de nganga mbulungu. Assis Júnior, Dicionário kimbundu-português, p. 39.

154 “Bulungo" in Óscar Ribas, Dicionário de regionalismos angolanos, Luanda: Fenacult, 2014, pp. 207-208. 
quilundos - termo do qual deriva calundu -, saquelamentos, zumbi e juramentos de bulungo". ${ }^{155}$ Apesar de os juramentos de bulungo - como os quilundos, zumbi e saquelamentos - terem por objetivo descobrir a ação de espíritos descontentes/feiticeiros sobre a vida dos consulentes, tratavam-se de rituais específicos, sobressaindo o seu caráter judicial-punitivo. Como se verá, esses “juramentos ambundus” buscavam uma eficácia imediata na descoberta e punição dos culpados.

O juramento de bulungo era um ordálio, ou seja: "prova mágica de inocência ou culpabilidade"; 156 tratava-se de uma forma de adivinhação centro-africana, espécie de investigação que tomava a forma de prova física. "O adivinho invocava o mundo espiritual para que este revelasse a culpabilidade ou inocência dos suspeitos”157 - era, assim, um instrumento religioso-judicial típico da África Central. Por esse "juramento" (ritual de adivinhação), descobria-se quem dos suspeitos era, de fato, o feiticeiro, ladrão ou assassino que rompia o equilíbrio de uma determinada comunidade. ${ }^{158} \mathrm{O}$ procedimento de adivinhação era geralmente usado para confirmar a culpa de pessoas suspeitas, que, uma vez trazidas à presença do adivinho, passavam pelo ritual. Já que se destinava a resolver um conflito comunitário, esse ritual descreve um drama social, no sentido empregado pelo antropólogo Victor Turner.

Turner, que estudou os Ndembo (Dembo) da África central, afirmou que a adivinhação era "uma fase no processo social que começa com uma morte, doença, distúrbio reprodutivo ou infortúnio na caça (pois a doença é apenas um dos tipos de infortúnio que têm causas místicas)”."159 Esse processo de adivinhação tinha início com uma discussão no grupo de parentesco ou aldeia da vítima. O segundo passo - o mais importante - era a consulta a um adivinho. “Acreditava-se que os adivinhos distantes

155 Marcussi, “Utopias centro-africanas”, p. 22.

156 "Bulungo", p. 207.

157 Sweet, Recriar África, p. 147.

158 Como advertiu James Sweet, “a adivinhação africana funcionava como uma forma de atingir o equilíbrio e a harmonia na comunidade”. Sweet, Recriar África, p. 149.

159 Turner, Florestas de símbolos, p. 451. 
dão diagnósticos mais confiáveis do que os mais próximos”160 - isso também explica o motivo da sociedade religiosa de Catarina Juliana buscar mestres de cerimônias nos sertões angolanos. A etapa seguinte do processo de adivinhação era a consulta ou sessão propriamente dita, em que os parentes das vítimas e os vizinhos tomavam parte. Finalmente, ocorriam ações terapêuticas prescritas pelo adivinho, que tinham o objetivo de restabelecer o equilíbrio rompido na família ou comunidade ou seja, a expulsão do feiticeiro/bruxa, descoberta do ladrão ou assassino etc. Aplicavam-se "poções feitas de ervas ou de outras substâncias por um herborista ou curandeiro, segundo os conselhos do adivinho”. ${ }^{161}$

Embora as pesquisas de campo de Turner remontem aos anos 1950-1960, sua descrição parece conter elementos que condizem com o ritual que, nas denúncias contra Catarina Juliana, foi chamado de “juramento de bulungo". A busca de adivinhos nos sertões, a reunião de suspeitos em uma sessão e a utilização de ervas são elementos em conformidade com as descrições de Turner. Porém, este ritual de julgamento se transformou ao longo do tempo. Nos séculos XVII e XVIII, as ervas não eram usadas apenas com fins terapêuticos, mas, sobretudo, para apontar (através de forças místicas) o culpado, que, ao ingerir ervas eméticas e venenosas (um dos significados de mbúlungu, como apontado), tinha vômitos e poderia, até mesmo, morrer envenenado. Apesar destas similaridades, devemos buscar elementos de comparação em outros rituais de adivinhação (julgamentos) descritos por missionários que estiveram em Angola em épocas mais próximas à de Catarina Juliana, pois, como advertiu John K. Thornton, “um depoimento de uma testemunha ocular contemporânea, apesar de todos os problemas [como o etnocentrismo religioso], é ainda a pedra filosofal do ofício dos historiadores”. ${ }^{162}$

160 Turner, Florestas de símbolos, p. 451.

161 “Quaisquer que sejam os benefícios empíricos de certos tratamentos, as poções de ervas, segundo os Ndembu, derivam sua eficácia de noções místicas, e a terapia nativa é uma parte intrínseca do sistema mágico-religioso”. Turner, Florestas de símbolos, p. 451.

162 Thornton, “Religião e vida cerimonial”, p. 84. 
Cavazzi, que viajou por Angola no século XVII, narrou, em Descrição histórica dos três Reinos do Congo, Matamba e Angola, um ritual de adivinhação centro-africano chamado jaji: “O feiticeiro põe uma pedra em uma panela de água. [...] Quando a água ferve, o acusado é obrigado a retirar a pedra com a sua mão. Se se queima, é considerado culpado; se não sofre qualquer mal, cada um dos presentes o considera inocente, sem qualquer outra questão”163 (Figura 4).

Figura 4

Ritual de adivinhação denominado jaji (Angola, século XVII)

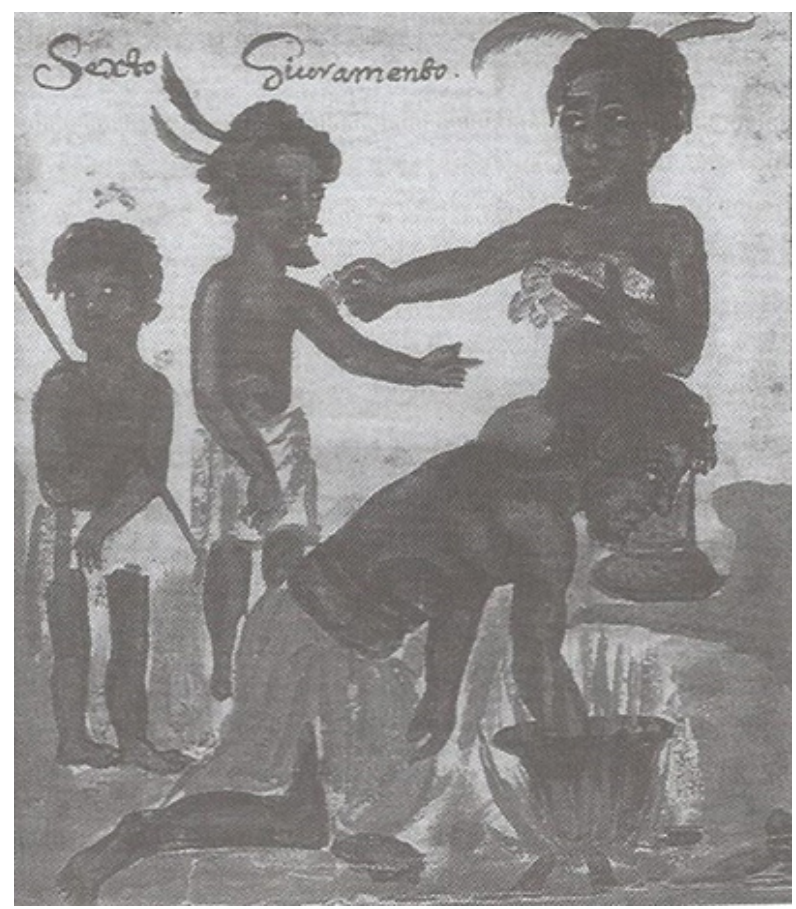

Fonte: Cavazzi, Manoscritti Araldi.

163 Cavazzi, Descrição histórica, p. 109. 
Descrição semelhante é dada pelo padre Girolamo Merolla, que esteve em Angola no mesmo século: o "feiticeiro” tirava a pedra da água a ferver "com a mão nua, ordenando aos outros que fizessem o mesmo; aqueles que a tiram sem se escaldarem são considerados inocentes, enquanto que o contrário expõe a sua culpa”. 164

Estes rituais de adivinhação foram trazidos para as Américas com a diáspora africana promovida pela escravidão transatlântica moderna. James Sweet descreve um rito de adivinhação centro-africano que se parece com o julgamento do jaji. Esse ritual ocorreu na Bahia, em uma pequena ilha perto da Ilha da Maré, e nele pretendia-se descobrir o ladrão de um tecido na fazenda de Duarte Roiz Ulhoa:

um escravo chamado Gunza preparou um bálsamo, que misturou em um prato. Uma vez terminada a preparação do bálsamo, esfregou uma pequena quantidade nos braços de todas as pessoas que estavam a assistir ao ritual. Após efetuar a unção de cada braço, Gunza passava uma agulha pelo mesmo. Prometeu que aqueles que não tivessem roubado o pano não sofreriam qualquer ferimento - apenas o culpado sangraria. Após ilibar desta forma todos os suspeitos que estavam reunidos para o julgamento, incluindo alguns brancos, Gunza começou a realizar o ritual no seu próprio corpo, dizendo o nome de potenciais suspeitos que se encontravam ausentes. Introduziu a agulha no seu braço uma e outra vez, dizendo "em nome de fulano de tal [...] se ele roubou o pano o meu braço vai sangrar”. 165

De fato, como observou Alexandre Marcussi, no Brasil colonial alguns desses rituais de adivinhação se aparentavam com os calundus. ${ }^{166}$

164 Girolamo Merolla da Sorrento, Breve, e succinta relatione del viaggio nel regno di Congo nell'Africa Meridionale, Nápoles: Fracesco Mollo, 1962, p. 98. Este ritual é descrito também por António de Oliveira Cadornega, História geral das guerras angolanas, 1680, Lisboa: Agência Geral das Colónias, 1949-1942, v. 3, pp. 319-320.

165 Sweet, Recriar África, p. 151.

166 Marcussi, “Utopias centro-africanas”, p. 22. 
A exemplo do que tem sido observado nas Américas, a sobreposição de diferentes práticas religiosas (judiciárias e de culto aos ancestrais e minkisi) em Catarina Juliana leva a crer que, na Angola de meados do século XVIII, ocorreu uma concentração cultural de diferentes papéis religiosos na figura de um único sacerdote - padrão que difere daquele apresentado por cronistas seiscentistas que, como Cavazzi, descrevem rituais centro-africanos regidos por diferentes agentes religiosos. No Brasil colonial, todavia, as heterogêneas práticas religiosas - ao contrário do que ocorreu no processo de Catarina Juliana - eram geralmente descritas debaixo de um termo guarda-chuva: "calundus".

Sobre o uso da adivinhação como meio de solucionar conflitos sociais, Victor Turner advertiu que a consulta do adivinho era o episódio central do processo, pois se olhava "tanto para trás - buscando as causas -, quanto para frente, propondo medidas terapêuticas”. ${ }^{167}$ As sessões de adivinhação que Turner assistiu entre os Ndembos nos anos 1950-1960, porém, continham algo de próximo a uma análise psicológica comunitária, o que parece estar em desacordo com os rituais descritos pelos missionários do século XVII. De acordo com Turner, “os adivinhos tentam obter de seus clientes respostas que possam lhes dar dicas sobre o padrão das tensões em seus grupos de origem". ${ }^{168}$ Assim, o processo de adivinhação "se torna uma forma de análise social, no decorrer da qual as lutas encobertas entre indivíduos e facções são reveladas para que possam ser resolvidas por meio de procedimentos tradicionais”. ${ }^{169}$ Ressalta-se, aqui, o caráter terapêutico da consulta ao adivinho/curandeiro, enquanto que no caso de Catarina Juliana sobressai o caráter judicial-punitivo daquele que cometeu o delito/ feitiçaria. Entre os Ndembos dos anos 1950-1960, o ritual promovia uma correção social; na sociedade de Catarina Juliana dos anos 1740-1750, realizava uma punição social. Nas duas situações pretendia-se restabelecer

167 Turner, Florestas de símbolos, pp. 451-452.

168 Turner, Florestas de símbolos, pp. 451-452.

169 Turner, Florestas de símbolos, pp. 451-452. 
o equilíbrio social rompido por alguém, mas no "juramento bulungo" do século XVIII tratava-se, ainda, de punir o culpado, envenenando-o. ${ }^{170}$

Essa espécie de "tribunal religioso" era muito comum no reino de Angola, e muitas autoridades locais recorriam aos "juramentos ambundus" para solucionar os seus conflitos, o que nos leva a crer que os oficiais angolanos, apesar de investidos com patentes militares portuguesas, permaneciam fiéis às suas tradições jurídicas locais, não recorrendo sempre às instâncias portuguesas. Desse modo, o “código de leis” mais eficaz a ser consultado, na visão dos colonos africanos, era aquele das adivinhações realizadas por intermédio da invocação de espíritos e entidades locais, e não as ordenações do reino de Portugal, tal como eram aplicadas por juízes com formação universitária. No distrito de Golungo, por exemplo, Joaquim José de Lima, natural e militar auxiliar em Luanda, foi denunciado, em 1794, aos inquisidores portugueses por mandar "fazer juramentos supersticiosos chamados pelo idioma da terra de bulungo, com adivinhações e invocações do demônio, para se adivinhar o feiticeiro responsável pela moléstia de sua amásia ou concubina, a preta Engracia Francisco". ${ }^{171}$

$\mathrm{O}$ adivinho, que presidia os juramentos de bulungo realizados pela sociedade religiosa de Catarina Juliana, era, mais uma vez, o já citado Antônio Cambundo. ${ }^{172}$ Uma das testemunhas ouvidas no processo afirmou que, na ocasião em que estes juramentos ambundus eram realizados, a sociedade religiosa denunciada dava adoração e consultava os “ídolos Mutacalambo, Gangazumba e Quibuco”. ${ }^{173}$ Portanto, as consultas

170 John K. Thornton assinala que, no Loango, os iniciados nos altares de divindades territoriais, caso mentissem em seus juramentos, poderiam ser assassinados pela força mística: "Os jovens eram iniciados no culto de Maramba e faziam um juramento quando terminavam seu curso. Guardião da moral pública, o santuário mataria qualquer um que mentisse enquanto o adotasse” - Thornton, "Religião e vida cerimonial”, p. 88.

171 ANTT, TSOIL, DA, cx. 1582, cód. 13961, Denúncias contra Joaquim José de Lima, 9 maio 1794, fl. 1 .

172 ANTT, TSOIL, DA, cx. 1580, cód. 13839, Correspondência de Catarina Juliana, fl. 98v.

173 ANTT, TSOIL, DA, cx. 1580, cód. 13839, Correspondência de Catarina Juliana, fl. 38 . 
a divindades que vinham às cabeças de Catarina Juliana, da negra Luzia e do escravo Teodósio eram realizadas para a adivinhação e a cura. Não sabemos qual era a entidade consultada pelo mestre da cerimônia, o nganga Antônio Cambundo, mas, como algumas testemunhas apontaram que os minkisi adorados na casa do capitão-mor João Pereira da Cunha foram trazidos por esse "mágico do sertão”, parece factível que uma das três entidades citadas acima viesse à cabeça de Antônio Cambundo. Como ocorria nos rituais de cura, nas cerimônias de adivinhação os consulentes eram iniciados na sociedade religiosa. Nas palavras de Turner: “o paciente de qualquer tipo de ritual de um culto se torna um candidato a entrar no mesmo e, após passar pelos seus ritos [liminaridade], se tornar um adepto dele”. ${ }^{174}$

\section{Considerações finais}

Este artigo analisou as práticas religiosas realizadas durante a década de 1740 pela comunidade de culto de Catarina Juliana, uma sacerdotisa liberta de Angola que foi presa pela inquisição portuguesa em 1750. A partir da trajetória religiosa de nossa protagonista e de seus “sócios”, procuramos descrever e interpretar as formas assumidas pelos rituais religiosos, tal como eram praticados na Angola do século XVIII.

Os rituais africanos descritos neste artigo permaneceram separados do catolicismo em uma região interiorana da Angola colonizada pelos portugueses, passando da condição pré-colonial de cultos oficiais para a situação colonial de cultos periféricos. A sociedade religiosa de Catarina Juliana, embora formada por indivíduos batizados, não operou um sincretismo religioso. Nossas conclusões aproximam-se, portanto, das de James Sweet, para quem as religiões africanas permaneceram apartadas do catolicismo, consistindo em cosmologias contra-hegemônicas.

174 Turner, Florestas de símbolos, p. 452. 
Como notaram os governadores, missionários e viajantes portugueses, em Angola - sobretudo nos presídios interioranos - as práticas cristãs se africanizaram e a maior parte da população, ainda que batizada, continuou a praticar os "ritos gentílicos". Catarina Juliana era batizada, mas iniciou-se como sacerdotisa após receber um chamamento divino em forma de doença e procurar uma nganga do sertão angolano, chamada Esperança Cazolla, para curá-la. Uma vez iniciada como xinguila e nganga-nkisi, Catarina Juliana passou a integrar a sua própria sociedade religiosa, realizando rituais na casa de seu ex-senhor e amante, o capitão-mor João Pereira da Cunha, como também em campo aberto, em meio a baobás sagrados. Catarina Juliana atendia os seus consulentes como xinguila, ou seja: médium que recebe espíritos de antepassados, cultuando entidades como nganga-nkisi para aumentar a força vital de sua comunidade religiosa - sendo Gangazumba o nkisi que vinha à sua cabeça.

Observamos que os rituais de culto às entidades (propiciadores do aumento da força vital), de apaziguamento de espíritos de antepassados de consulentes (cura), de enterro de antepassados mortos (entambes) e de promoção de tribunais sobrenaturais para estabelecer a culpa e punição de suspeitos de malefícios (adivinhação) constituíam rituais específicos em Angola (ainda que pudessem estar interligados), mas se sobrepunham em uma única sacerdotisa e sua sociedade de culto. Essa sobreposição sugere processos de transformação e concentração cultural - semelhantes aos que outros pesquisadores observaram nas Américas - em que um mesmo sacerdote assume responsabilidades e papéis que eram realizados por diferentes agentes religiosos nas sociedades centro-africanas do século XVII.

Constatamos que alguns dos nkinsis cultuados pela sociedade religiosa de Catarina Juliana, na Angola de meados do século XVIII (Gangazumba, Mutacalombo e Quibuco), estão presentes nos atuais candomblés angolas brasileiros, sem que, com isso, decorra uma continuidade a-histórica desses rituais. Não pretendemos traçar uma linha direta entre os rituais descritos neste artigo e os candomblés angolas 
contemporâneos, mas tão-somente apontar a continuidade do culto a determinadas entidades (ainda que a morfologia ritual tenha se transformado ao longo do tempo), o que nos permite revisar visões equivocadas de alguns dos fundadores dos estudos das religiões afro-brasileiras e defensores de purismos, que afirmaram que os nomes das entidades dos candomblés bantu foram inventados e as suas formas rituais copiadas dos candomblés jeje-nagôs.

A análise morfológica das consultas aos minkisi apontou para um continuum objeto-pessoa-divindade, ou seja: para a indissociabilidade entre sacerdotes, entidades e objetos de culto nas práticas da sociedade religiosa analisada. Apesar de não possuir uma estrutura de tipo conventual, como os antropólogos verificaram na África Ocidental, a sociedade religiosa de Catarina Juliana possuía uma organização interna e transmitia os saberes através de iniciações pontuais de tipo cura-iniciação. As cerimônias empreendidas pela sociedade religiosa estudada não ocorriam apenas na casa em que estavam os minkisi, mas também fora do presídio de Ambaca, no campo em meio a baobás sagrados, onde eram celebrados ritos restituidores da eficácia dos entambes - apesar deles começarem nos campos e terminarem na casa de culto, em Ambaca.

Recebido em 30 jun. 2020

Aprovado em 29 dez. 2020

doi: 10.9771/aa.v0i63.37664 
Este artigo descreve e interpreta as práticas religiosas realizadas pela sacerdotisa angolana Catarina Juliana (e sua sociedade de culto) em uma região interiorana do reino de Angola durante o século XVIII. Os rituais e símbolos descritos no processo inquisitorial contra Catarina Juliana são interpretados a partir de uma análise hermenêutica e comparativa, e o aparato conceitual do estudo é fornecido pela antropologia simbólica. O caso analisado revela que angolanos, mesmo quando batizados na religião dos colonizadores, resistiam em suas práticas religiosas tradicionais. Procura-se, aqui, demonstrar que diferentes rituais, antes conduzidos por sacerdotes especializados, passaram a ser acumulados pelos banganga de uma mesma sociedade de culto na Angola setecentista.

Sociedade de culto | Práticas religiosas | Angola | Século XVIII

\section{Catarina Juliana and Her Cult Group:}

\section{Rituals and Religious Practices in Eightheenth Century Angola}

This article describes and interprets the religious practices performed by the Angolan priestess Catarina Juliana (and her cult group) in an inland region of the Kingdom of Angola during the 18th century. The rituals and symbols described in the inquisitorial process against Catarina Juliana are interpreted based on a hermeneutic and comparative analysis, using an approach coming from symbolic anthropology. The case analyzed shows that Angolans, even when baptized in the religion of the colonizers, continued their traditional religious practices. It seeks to demonstrate that different rituals, previously led by specialized priests, came to be accumulated by the banganga of the same cult society in 18th century Angola.

Cult society | Religious practices | Angola | 18th century 